\title{
Land Productivity and Economic Development: Caloric Suitability vs. Agricultural Suitability
}

\author{
Oded Galor* and Ömer Özak ${ }^{\dagger}$
}

July 12,2015

\begin{abstract}
This paper establishes that the Caloric Suitability Index (CSI) dominates the commonly used measure of agricultural suitability in the examination of the effect of land productivity on comparative economic development. The analysis demonstrates that the agricultural suitability index does not capture the large variation in the potential caloric yield across equally suitable land, reflecting the fact that land suitable for agriculture is not necessarily suitable for the most caloric-intensive crops. Hence, in light of the instrumental role played by caloric yield in sustaining and supporting population growth, and given importance of pre-industrial population density for the subsequent course of economic development, the Caloric Suitability Index dominates the conventional measure in capturing the effect of land productivity on pre-colonial population density and the subsequent course of economic development.

Keywords: Caloric Suitability, Agricultural Suitability, Agricultural Productivity, Land Productivity, Economic Development, Population Density

JEL Classification: O10, O40, Q10
\end{abstract}

*Department of Economics, Brown University. E-mail: Oded_Galor@brown.edu

${ }^{\dagger}$ Department of Economics, Southern Methodist University. E-mail: ozak@smu.edu 


\section{Introduction}

The role of geographical factors in comparative economic development at the national as well as the subnational level has been at the forefront of contemporary research on the persistent effect of deep-rooted factors in the differential development paths across nations and regions. In particular, land productivity has been shown to be conducive for economic development in the pre-colonial era and detrimental for prosperity in the post-colonial world.

The examination of the effect of land productivity has been based in recent years on an index of the suitability of land for agriculture (Ramankutty et al., 2002), which measures the fraction of each $0.5 \times 0.5$ degrees grid cell that is suitable for agriculture. This index, however, does not capture the large variation in the potential caloric yield across equally suitable land. In particular, geographical regions that according to this index are comparable in terms of their suitability for agriculture may differ significantly in their potential caloric output, reflecting the fact that land suitable for agriculture is not necessarily suitable for the most productive crops in terms of their caloric return.

Thus, in light of the importance of pre-industrial population density for the subsequent course of economic development, and given the instrumental role played by caloric yield in sustaining and supporting population growth, it is rather apparent that this commonly used index is not well designed to properly capture the effect of the suitability of land for agriculture on economic development.

Galor and Özak (2014) introduce a novel methodology that can be used to construct a refined measure of agricultural productivity based on the caloric potential of each grid cell on planet earth. The proposed Caloric Suitability Index (CSI) rectifies the deficiencies of the agricultural suitability index of Ramankutty et al. (2002), as well as other measures based on the FAO data that have measured agriculture output in tons rather than in caloric yield, and introduce a novel and comparable measure of agricultural suitability that properly captures the variation in potential crop yield across the globe, as accounted for by calories per hectare per year. Furthermore, in light of the expansion of crops amenable for cultivation in the course of the Columbian Exchange (Crosby, 1972), the index accounts for the changes in land productivity in the post-1500 period. Finally, focusing on potential crop yield, based on agro-climatic characteristics that are unaffected by human intervention, this measure can viewed as an exogenous proxy for land productivity.

This paper explores the virtues of the Caloric Suitability Index (CSI) in comparison to the index of agricultural suitability, demonstrating that effect of Caloric Suitability Index (CSI) on population density in the pre-colonial period is highly significant economically and statistically, whereas the effect of land suitability vanishes, once the CSI is accounted for. 
Moreover the paper and its online companion provides four estimates of caloric suitability for each cell of size $5^{\prime} \times 5^{\prime}$ in the world:

1. The maximum potential caloric yield attainable given the set of crops that are suitable for cultivation in the pre-1500 period.

2. The maximum potential caloric yield attainable, given the set of crops that are suitable for cultivation in the post-1500 period.

3. The average potential yields within each cell attainable given the set of crops that are suitable for cultivation in the pre-1500 period.

4. The average potential yields within each cell attainable given the set of crops that are suitable for cultivation in the post-1500 period.

The rest of the paper is structured as follows. section 2 explains the construction of the Caloric Suitability Index. Section 3 depicts the spatial distribution of agricultural productivity based on the CSI and the agricultural suitability index. Section 4 analyzes the virtues of the CSI in comparison to the agricultural suitability index. Section 5 examines the effect of CSI on pre-colonial development and Section 6 concludes. Appendix A provides instructions, links to the data and other resources.

\section{The Caloric Suitability Indices Data}

The Caloric Suitability Indices are constructed based on data from the Global AgroEcological Zones (GAEZ) project of the Food and Agriculture Organization (FAO). The GAEZ project supplies global estimates of crop yield for 48 crops in grids with cells size of $5^{\prime} \times 5^{\prime}$ (i.e., approximately $100 \mathrm{~km}^{2}$ ).

The estimates are available for: alfalfa, banana, barley, buckwheat, cabbage, cacao, carrot, cassava, chickpea, citrus, coconut, coffee, cotton, cowpea, dry pea, flax, foxtail millet, greengram, groundnuts, indigo rice, maize, oat, oilpalm, olive, onion, palm heart, pearl millet, phaseolus bean, pigeon pea, rye, sorghum, soybean, sunflower, sweet potato, tea, tomato, wetland rice, wheat, spring wheat, winter wheat, white potato, yams, giant yams, subtropical sorghum, tropical highland sorghum, tropical lowland sorghum, and white yams.

For each crop, GAEZ provides estimates for crop yield based on three alternative levels of inputs - high, medium, and low - and two possible categories of sources of water supply - rain-fed and irrigation. Additionally, for each input-water source category, it provides two separate estimates for crop yield, based on agro-climatic conditions, that are arguably unaffected by human intervention, and agro-ecological constraints, that could potentially reflect human intervention. 
In order to capture the conditions that were prevalent during the pre-industrial era, while mitigating potential endogeneity concerns, the indices use the estimates of potential crop yield under low level of inputs and rain-fed agriculture - cultivation methods that characterized early stages of development. Moreover, the estimates of potential crop yield are based on agro-climatic constraints that are largely orthogonal to human intervention. Thus, these restrictions remove the potential concern that the level of agricultural inputs, the irrigation method, and soil quality, reflect endogenous choices that could be potentially correlated with individual preferences or institutional settings. ${ }^{1}$

The FAO dataset provides for each cell in the agro-climatic grid the potential yield for each crop (measured in tons, per hectare, per year). These estimates account for the effect of temperature and moisture on the growth of the crop, the impact of pests, diseases and weeds on the yield, as well as climatic related "workability constraints".

In order to better capture the nutritional differences across crops, and thus to ensure comparability in the measure of crop yield, the yield of each crop in the GAEZ data (measured in tons, per hectare, per year) is converted into caloric return (measured in millions of kilo calories, per hectare, per year). This conversion is based on the caloric content of crops, as provided by the United States Department of Agriculture Nutrient Database for Standard Reference. Using the estimates of the caloric content for each crop in the GAEZ data (measured in kilo calories per $1 \mathrm{~g}$ ), a comparable measure of crop yield (in millions of kilo calories, per hectare, per year) is constructed for each crop.

In light of the expansion in the set of crops that were available for cultivation in each region in the course of the Columbian exchange, the constructed indices distinguish between the caloric suitability in the pre-1500 period and in the post 1500 period. In particular, the pre-1500 estimates are based on the 48 crops in the GAEZ/FAO data set, which were available for cultivation in each region of the world before 1500CE, as documented in Table 10 (Crosby, 1972; Diamond, 1997). ${ }^{2}$ In the post 1500CE period, in contrast, all 48 crops could potentially be adopted into agricultural production. ${ }^{3}$

\footnotetext{
${ }^{1}$ Additionally, the choice of rain-fed conditions is further justified by the fact that, although some societies had access to irrigation prior to the industrial revolution, GAEZ's data only provides estimates based on irrigation infrastructure available during the late twentieth century.

${ }^{2}$ The presence of the Asian varieties of rice (Oryza sativa) in Subsaharan Africa in the pre-1500CE period has been debated. In particular, the assignment of wetland (Oryza japonica) and indica (Oryza indica) rice varieties present in the GAEZ data to Subsaharan Africa prior to 1500CE is questionable. Hence, the CSI provide estimates based on the inclusion and the exclusion of Asian crops among those available for cultivation in Subsaharan Africa. It should be noted that while the regression analysis in Section 5 include the Asian varieties, their exclusion magnifies the economic and statistical significance of the CSI in comparison to the agricultural suitability index.

${ }^{3}$ In fact, as Crosby (1972) shows, many of the crops were quickly transplanted between the Old and New Worlds.
} 


\subsection{Caloric Suitability Within a Cell}

This section provides measures for the average and maximum caloric suitability with each cell. ${ }^{4}$ First, for each cell the average caloric yield across all available crops pre- and post$1500 \mathrm{CE}$ is computed. In particular, for any given cell $c$, the average caloric yield is $e_{c t}=$ $\sum_{i \in \mathcal{C}_{c t}} e_{i c} /\left|\mathcal{C}_{c t}\right|$, where $e_{i c}$ is the caloric yield per hectare per year of crop $i$ in cell $c$, and crop $i$ belongs to the set of crops available in the cell in period $t, \mathcal{C}_{c t}$. Notice that the average caloric yield in cell $c$ in period $t, e_{c t}$ is affected by the total number of crops available, which might include crops not productive in that particular cell. Thus, this measure penalizes the average caloric yield in cells where not all crops are productive. For this reason, an alternative measure that excludes non-productive crops from the average for each cell is provided. This alternative index measures the average caloric yield in cell $c$ in period $t$, $e_{c t}^{0}=\sum_{i \in \mathcal{C}_{c t}^{0}} e_{i} /\left|\mathcal{C}_{c t}^{0}\right|$, for crops that are productive in the cell, i.e. $e_{i c}>0$. This avoids penalizing cell-level productivities due to the availability of crops that are not productive in a cell. Notice that for cells where all crops are productive, $e_{c t}=e_{c t}^{0}$. Furthermore, for cells where no crops are productive, $e_{c t}=0$ and $e_{c t}^{0}$ is set to missing, rather than zero that is assigned by the measure that includes all crops regardless of their level of productivity. For all other cells, it is the case that $e_{c t}<e_{c t}^{0}$.

Hence, this paper provides four measures of Average Caloric Suitability for each cell:

1. pre-1500CE (including crops with zero productivity)

2. pre-1500CE (excluding crops with zero productivity)

3. post-1500CE (including crops with zero productivity)

4. post-1500CE (excluding crops with zero productivity)

Second, following Galor and Özak (2014), the paper provides a measure of the Maximal Caloric Suitability for each cell for crops that were available for cultivation in the pre and post-1500CE period. In particular, for any given cell $c$, the maximum caloric yield is $e_{c t}^{*}=$ $\max _{i \in \mathcal{C}_{c t}} e_{i c}$. Notice that cells for which at least one crop is productive $e_{c t}^{*}=e_{c t}^{0 *}$ where $e_{c t}^{0 *}=\max _{i \in \mathcal{C}_{c t}^{0}} e_{i c}$. On the other hand, if no crop is productive $e_{c t}^{*}=0$ and $e_{c t}^{0 *}$ is set to missing. Using these two measures, the analysis builds four sets of grids of Maximum Caloric Suitability:

1. pre-1500CE (including crops with zero productivity)

\footnotetext{
${ }^{4}$ The measures constructed by Galor and Özak (2014) exclude bananas, cassava, and coconuts since the GAEZ/FAO data does not provide an estimate for their potential growth cycles. This restriction does not affect their analysis since they focus on the crops that yield the highest number of calories in each cell given the available crops in the pre-and post-1500CE period and these excluded crops are dominated by others.
} 
2. pre-1500CE (excluding crops with zero productivity)

3. post-1500CE (including crops with zero productivity)

4. post-1500CE (excluding crops with zero productivity)

While the analysis constructs and makes available only the Average and Maximum Caloric Suitability Indices, one can clearly construct other similar Caloric Suitability Indices based on other moments of the distribution of crops' caloric yields.

\subsection{Caloric Suitability Within a Country or Region}

Country- or regional-level measures can be constructed by computing the statistic of interest of a CSI measure over the cells located in the country or region. For example, the countrylevel average of the pre-1500CE Average CSI (all cells and crops) for country $C$ is computed as $e_{C t}=\sum_{c \in C} e_{c t} /|C|$ for $t=$ pre-1500CE. Notice that by construction, $e_{C t}$ penalizes the country-level average due to cells that are not productive for all crops. On the other hand,

$e_{C t}^{0}=\sum_{c \in C} e_{c t}^{0} /|C|$ excludes all cells that are not productive. As will be shown below both measures are highly positively correlated.

A third measure can be constructed, which does not penalize for unproductive crops, but includes the non-productive cells in the country- or regional-level analysis. Letting $w^{0}$ denote the share of non-calorically-productive land, then $e_{C t}^{00}=w^{0} \cdot e_{C t}^{0}$ measures the average caloric suitability in country $C$ over all productive crops at each cell and including all cells in the country. Thus, the analysis provides three different measures of caloric suitability at the country level. First, the average caloric suitability across all cells regardless of whether crops within the cell are productive or not. Second, the average caloric suitability for productive cells, including only productive crops within a cell. Third, the average caloric suitability across all cells, including only productive crops within a cell.

The CSI data can be used to assess the exogenous effect of agricultural potential on various economic and social outcomes. The following sections compare the CSI and agricultural suitability indices and establish their differential effects on pre-colonial population density and economic development.

\section{Caloric Crop Suitability and Agricultural Suitability}

This section explores the spatial distribution of agricultural productivity as captured by Caloric Suitability Indices (CSI) and agricultural suitability index (ASI). 


\subsection{Pre-1500CE Caloric Suitability Indices}
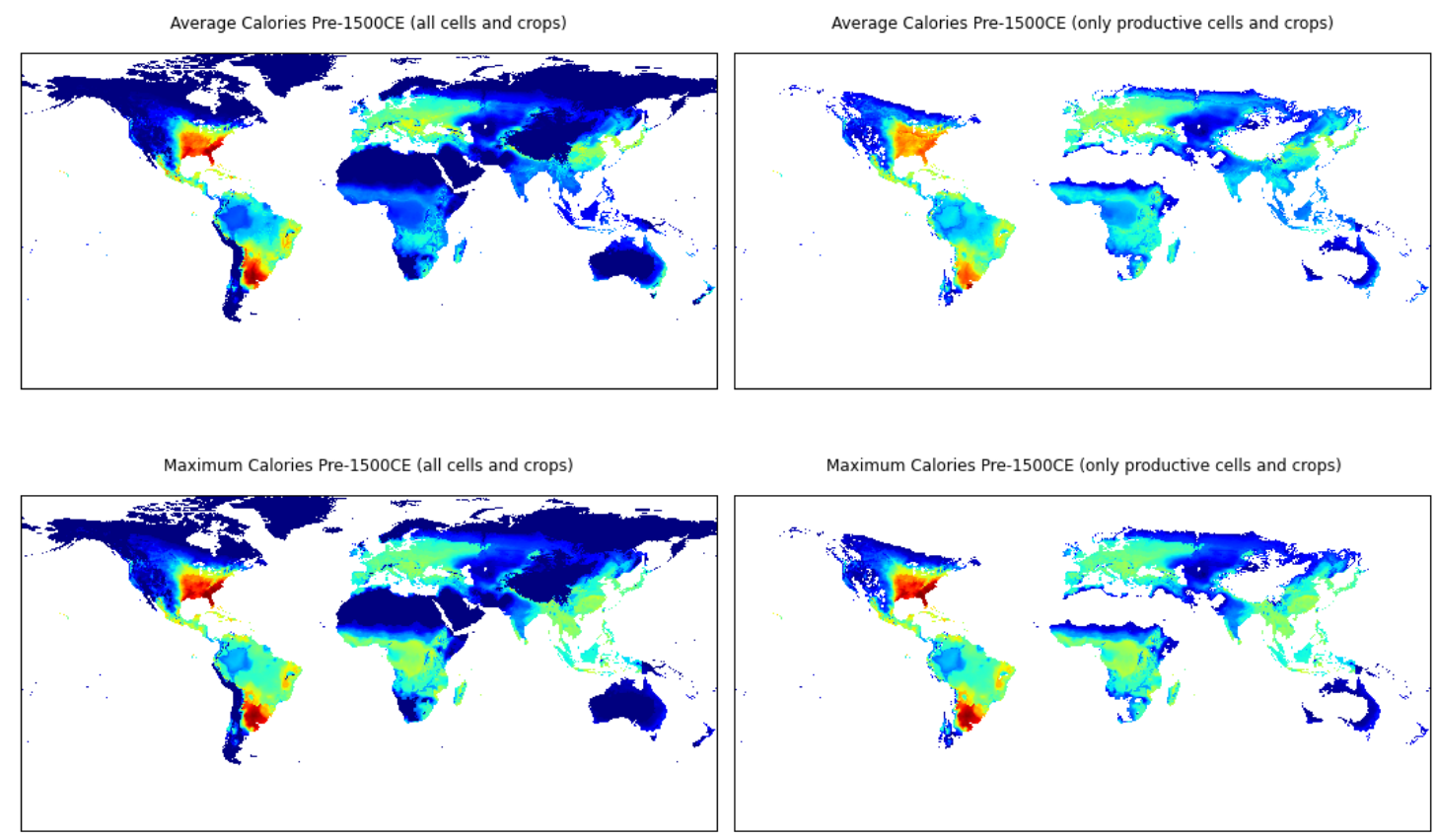

Figure 1: Pre-1500CE Caloric Suitability Indices (CSI)

Figure 1 depicts the distribution of land productivity across the globe as captured by the pre-1500CE CSI. It suggests that there are large geographical variations in the caloric suitability of land. Furthermore, there are large extents of land not suitable for the production of calories and, thus, to sustain settled human life.

Figure 2 depicts the relationship between the country-level measures of pre-1500CE CSI when all cells and crops are included and measures that include only productive cells and crops and those that consider all cells but only productive crops. As is apparent from the figures, the average pre-1500CE CSI, based on all cells and crops is lower than the other measures for most countries. In particular, countries above the $45^{\circ}$ line in panels (a) and (b) are the ones which have regions where not all crops or cells are productive. Similarly, panels (c) and (d) show that the maximum pre-1500CE CSI (including productive cells and crops) is higher only for countries that have regions where none of the crops are suitable. 


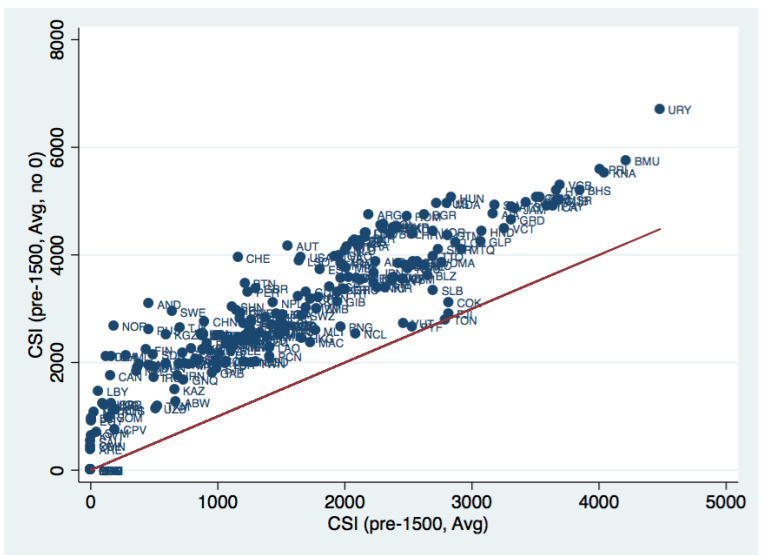

(a) Average CSI (all cells and crops) vs Average CSI (only productive cells and crops)

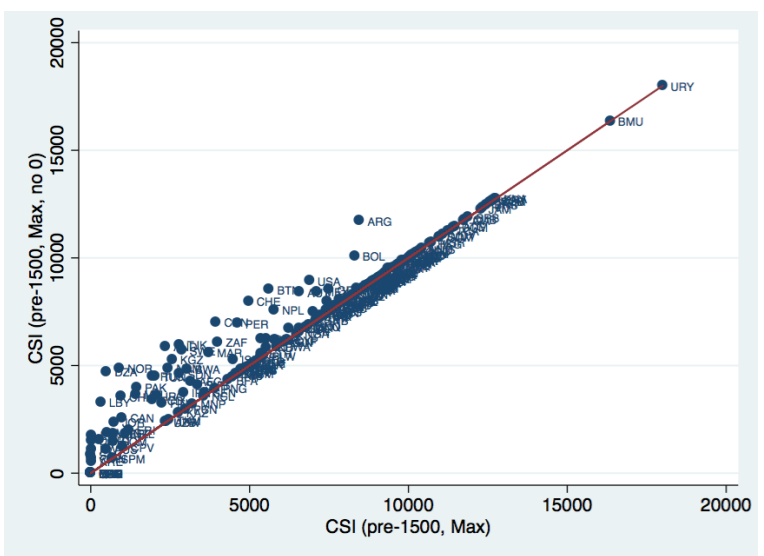

(c) Maximum CSI (all cells and crops) vs Maximum CSI (only productive cells and crops)

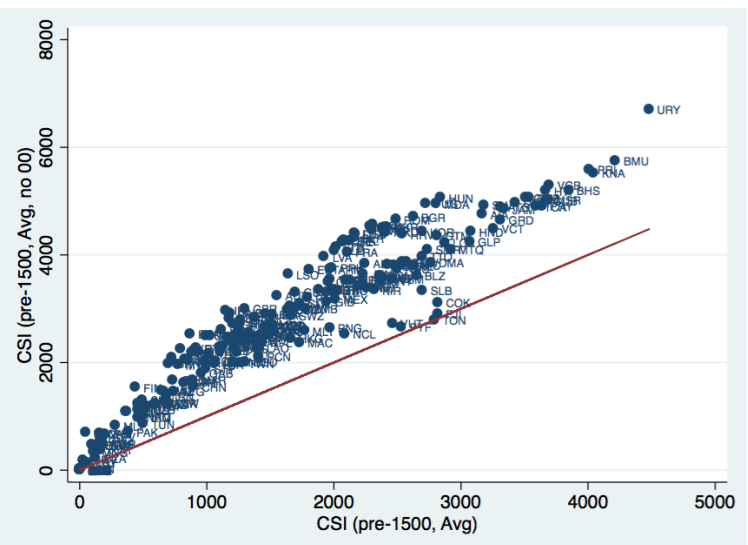

(b) Average CSI (all cells and crops) vs Average CSI (all cells and only productive crops)

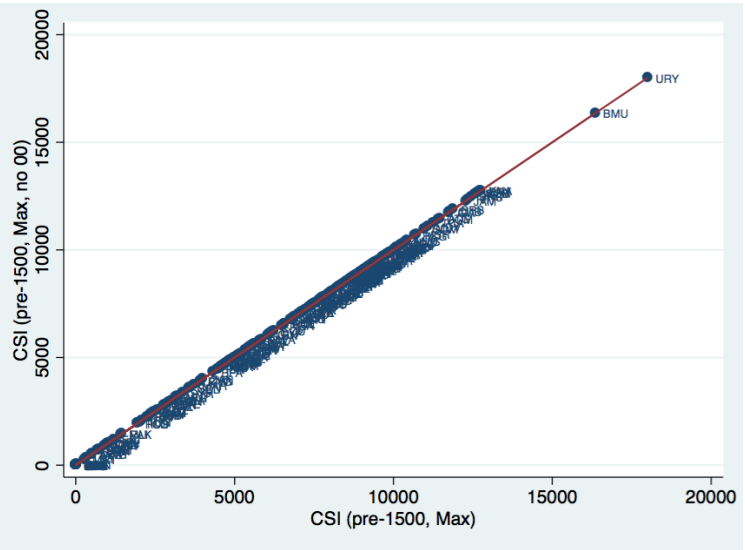

(d) Maximum CSI (all cells and crops) vs Maximum CSI (all cells and only productive crops)

Figure 2: Country-Level Measures of pre-1500CE Caloric Suitability Indices.

\subsection{Post-1500CE Caloric Suitability Indices}

Figure 3 shows the plots of the 4 rasters for the post-1500CE period. Again there are large geographical variations in the caloric suitability of land. Furthermore, there are large extents of land not suitable for the production of calories and, thus, to sustain settled human life, even after the expansion of crops generated by the Columbian Exchange.

Additionally, Figure 4 shows the relation between the country-level measures for the preand post-1500CE CIS data. As can be seen there, the expansion of crops generated by the Columbian Exchange weakly increased the Maximum CSI (only productive cells and crops) in all countries. This reflects the fact that by introducing new crops, the maximum caloric suitability in all cells in a country increase weakly. On the other hand, the other Maximum 

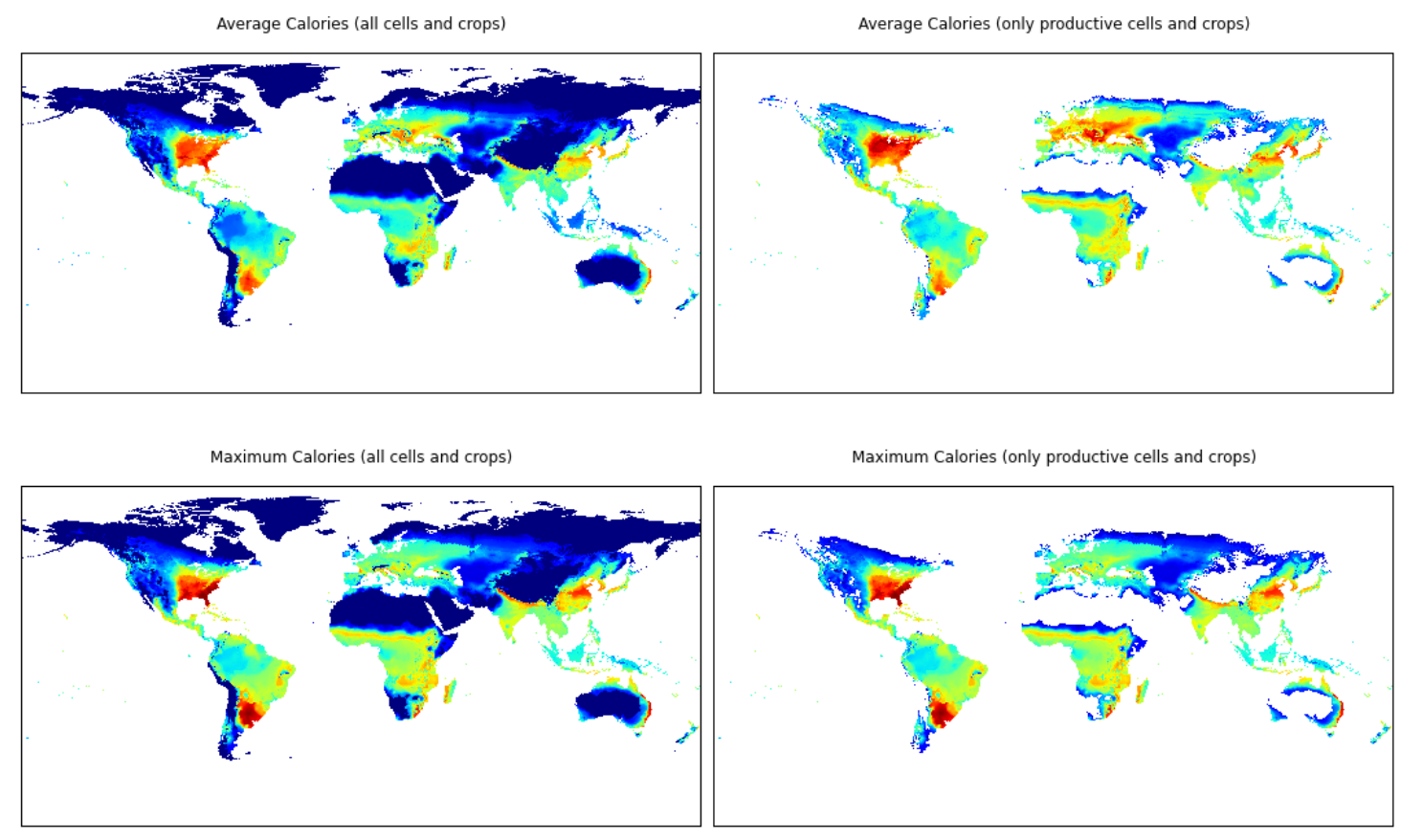

Figure 3: Post-1500CE Caloric Suitability Indices (CSI)

CSI measures can decrease, since the expansion of crops might allow the production of calories in locations where it was previously not possible, thus, possibly decreasing the countrylevel average. For similar reasons, the introduction of new crops has similar effects on the Average CSI (all cells and crops). Additionally, introduction of new crops might lower the average caloric output of each cell, thus possibly lowering the Average CSI (all cells and only productive crops). Thus, care must be taken when using the Columbian Exchange in research, since the question being analyzed may guide which measure better captures the effect of the expansion of crops. For example, research focused on increases in productivity generated by the Columbian Exchange may need to use the Maximum CSI (only productive cells and crops) (Galor and Özak, 2014) or constrain the analysis in some other way, like focusing on cells only where new crops allow the production to be above the country-level pre-1500CE average.

\subsection{Agricultural Suitability data}

Finally, Figure 5 shows the agricultural suitability data of Ramankutty et al. (2002), including the climatic and soil components of their index. As can be seen there, the main index 


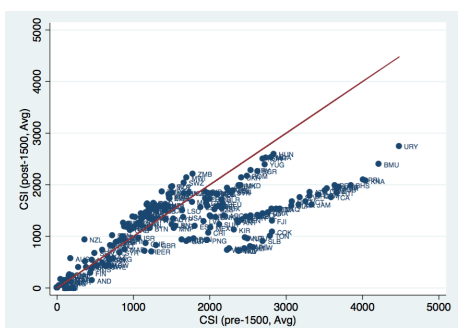

(a) Average CSI (all cells and crops)

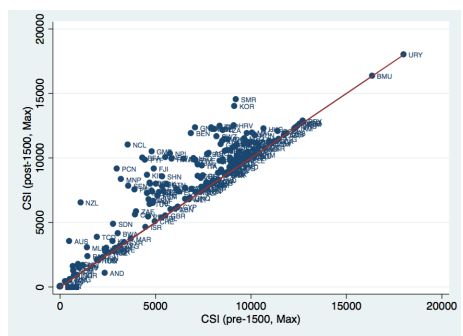

(d) Maximum CSI (all cells and crops)

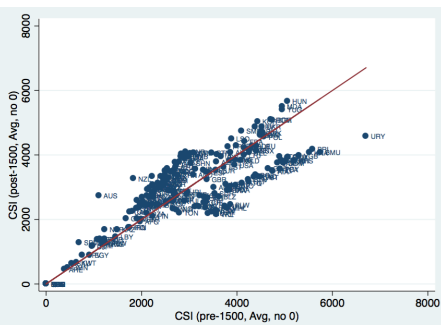

(b) Average CSI (only productive cells and crops)

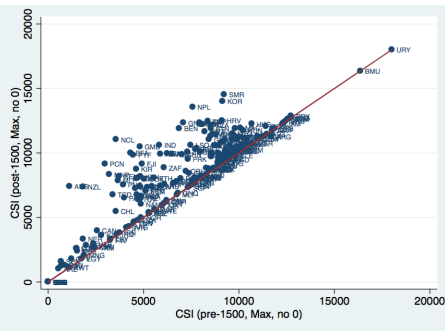

(e) Maximum (only productive cells and crops)

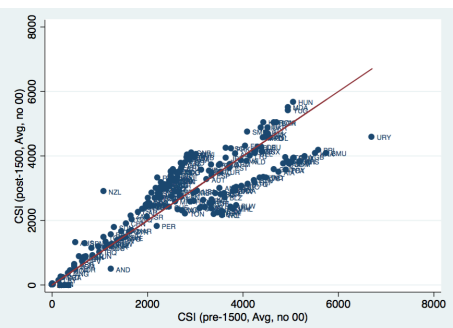

(c) Average CSI (all cells and only productive crops)

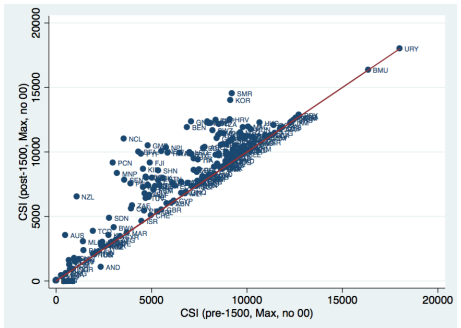

(f) Maximum CSI (all cells and only productive crops)

Figure 4: Country-Level Measures of pre- and post-1500CE Caloric Suitability Indices.

and the soil component have large subregional variations, while climatic component mostly varies across larger regions.

\section{Virtues of Caloric Suitability Index over Agricul- tural Suitability}

\subsection{Finer Resolutions}

The Ramankutty et al. (2002) data is constructed in grids of $0.5^{\circ} \times 0.5^{\circ}$ with 360 rows and 720 columns, while the Galor and Özak (2014) has a resolution of $5^{\prime} \times 5^{\prime}$ with 2160 rows and 4320 columns. So, each cell in the Ramankutty et al. (2002) data is equivalent to 36 cells in the Galor and Özak (2014) dataset. This means one can work at much smaller scales. In particular, this increases the number of countries for which data can be generated (see section 5). Additionally, less measurement error will be generated when extracting data for countries or smaller regions. 

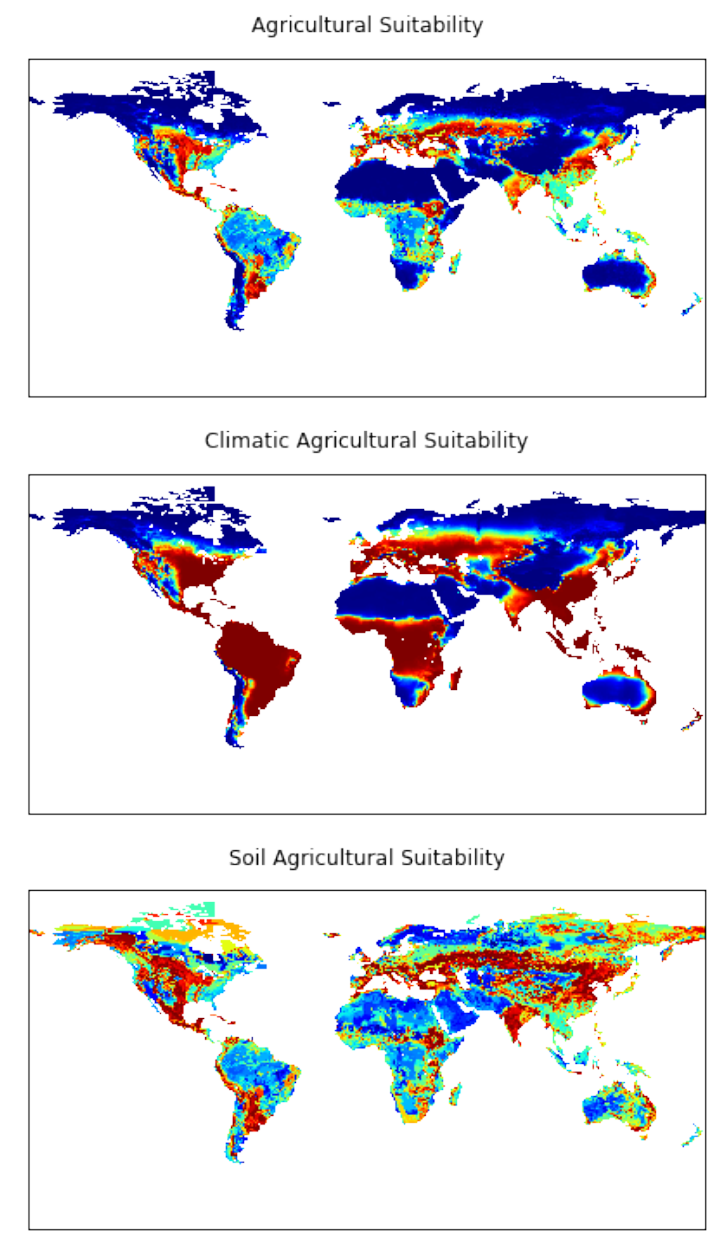

Figure 5: Agricultural Suitability

\subsection{Exogenous to Human Intervention}

The CSI data is based on agro-climatic conditions that are mostly orthogonal to human intervention. On the other hand, as can be seen in the figures, most of the variation in the Agricultural Suitability data comes from the Soil component and not from the Climatic component. Thus, the use of the Ramankutty et al. (2002) index in most economic research might be problematic, since for most research questions, especially in comparative development and long-run growth, the measure might be affected by human intervention.

\subsection{Existence of Temporal Variations}

By exploiting the Columbian Exchange, the CSI data capture the changes in productivity generated by the introduction of new crops. This provides temporal variation that can be used in the empirical analysis of economic development. No such variation is present or can 
be easily constructed for the agricultural suitability data of Ramankutty et al. (2002).

\subsection{Capture Elements Essential for Human Existence}

Human existence requires consumption of sufficient calories. Thus, one can expect that mankind would evolve in regions that allow the efficient production of calories. While one can expect that agricultural and caloric suitability be (positively) correlated, they clearly are not the same concept, nor do they measure the same underlying process. In particular, as the following figures show, for any given probability of a cell being suitable for agriculture (as measured by Ramankutty et al. (2002)), the Caloric Suitability Indices vary over the full range of their possible values. Figure 6 shows this result holds for the Post-1500CE CSI data. Similar results are obtained if instead one uses the Pre-1500CE Caloric Suitability Indices (Figure 7) or if one focuses on the climatic component of Agricultural Suitability (Figure 8). This evidence suggests that agricultural suitability does not properly capture this essential element.
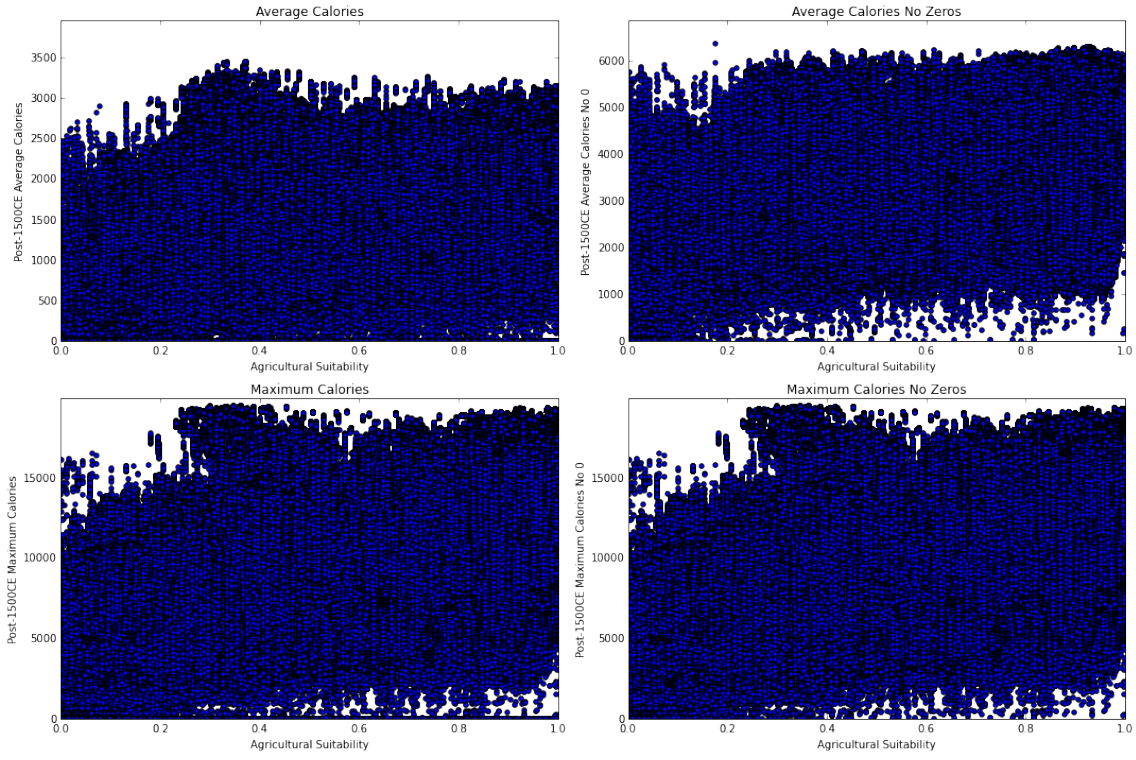

Figure 6: Post-1500CE Caloric Suitability and Agricultural Suitability

While these figures show that there is not a strong relation between both sets of indices, they can be misleading since they do not show the density or joint probability distribution. Figures 9 and 10 show histograms of the joint density of agricultural suitability and pre- and post-1500CE CSI. As can be seen there the joint distribution also has full domain.

Finally, Figure 11 shows the relation between pre-1500CE CSI and Agricultural Suitability at the country level. Although positively correlated, they clearly do not capture similar 

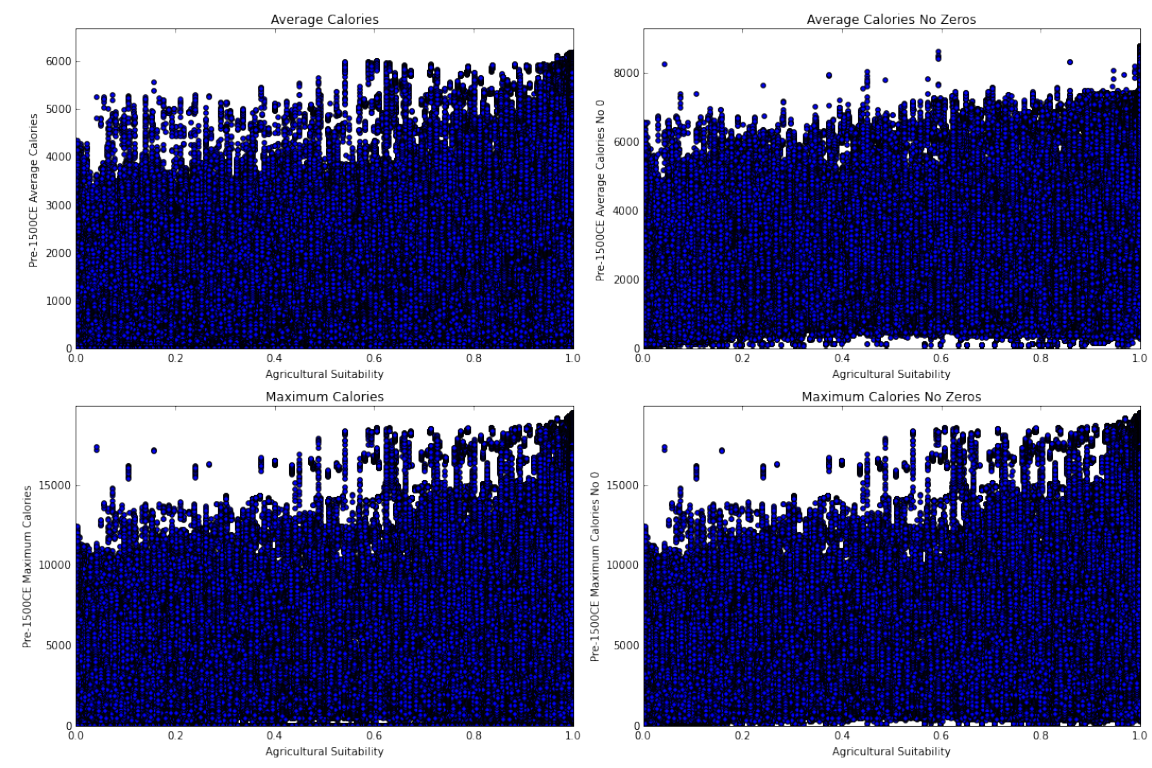

Figure 7: Pre-1500CE Caloric Suitability and Agricultural Suitability

phenomena. It is especially important to note the Maximum CSI measures and the Average CSI (only productive cells and crops) have the least clear linear relation with agricultural suitability.

\section{Caloric Suitability and Pre-Colonial Development}

This section analyzes the effect of caloric suitability on pre-colonial development through its effect on population density. In particular, it is known that during the Malthusian era, economic development increased population, which itself increased population density and technology (Ashraf and Galor, 2011; Özak, 2012). Thus, the differential levels of population density across countries determined their differential levels of economic development.

Clearly, a country's caloric suitability is an essential determinant of its level of population since it determines its carrying capacity. In particular, ceteris paribus, countries that have higher caloric suitabilities should be able to sustain larger populations. Using population density data for the years 1500CE, 1000CE and 1CE, this section shows that indeed countries with higher caloric suitabilities had higher population densities. Furthermore, once caloric suitabilities are accounted for, agricultural suitabilities do not have any additional explanatory (or predictive) power.

In particular, in order to explore the relation between caloric suitability and population density more systematically, variations of the following empirical specification are estimated 

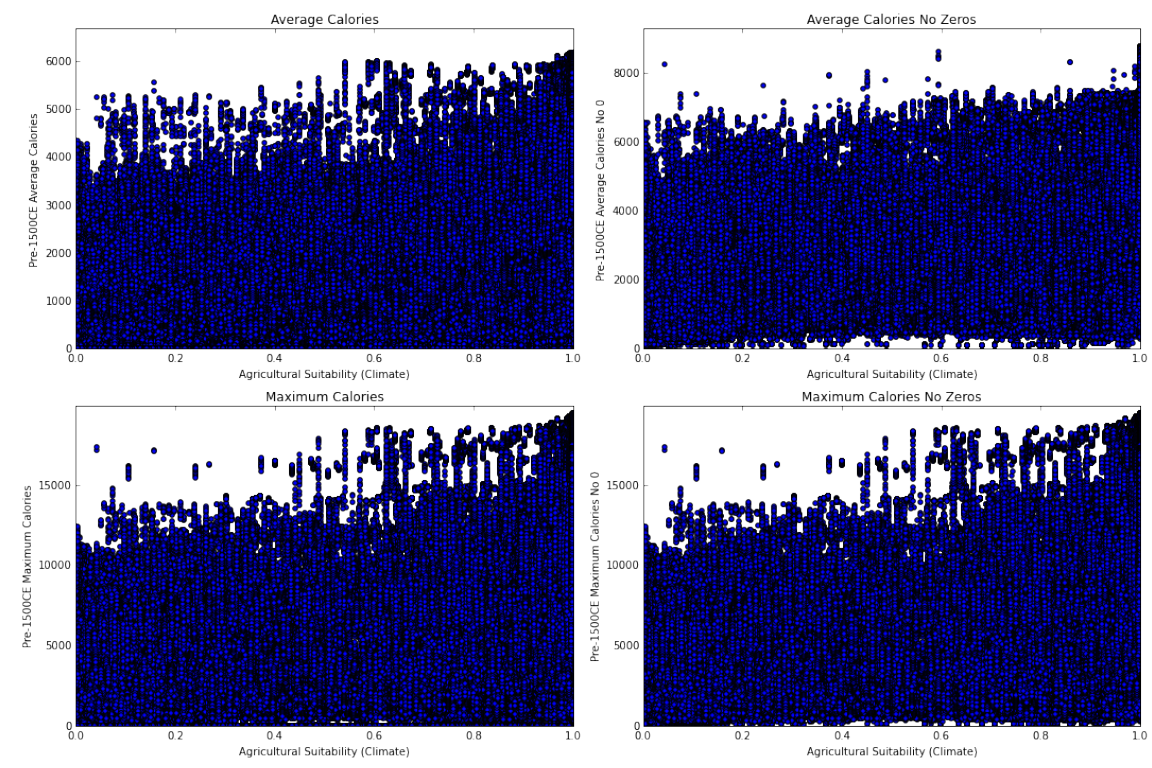

Figure 8: Pre-1500CE Caloric Suitability and Climatic Agricultural Suitability

via ordinary least squares (OLS):

$$
\ln \left(y_{i t}\right)=\beta_{0}+\beta_{1} \mathrm{CSI}_{i \mathrm{pre} 1500}+\beta_{2} \mathrm{ASI}_{i}+\sum_{j} \gamma_{0 j} X_{i j}+\gamma_{1} \mathrm{YST}_{i}+\sum_{c} \gamma_{c} \delta_{c}+\epsilon_{i t}
$$

where $y_{i t}$ is the population density of country $i$ in period $t=1,1000,1500$; CSI $_{i \text { pre1500 }}$ is the country $i$ 's level of pre-1500 CSI where the various measures are used in the analysis; $\mathrm{ASI}_{i}$ is a country's agricultural suitability; $X_{i j}$ is a set of country level geographical factors like absolute latitude, share of land within $100 \mathrm{kms}$ of sea, average elevation above sea level, ruggedness, average yearly temperature, average yearly precipitation, dummies for the country being landlocked or an island; $\mathrm{YST}_{i}$ are the number of years since the country transitioned to agriculture; and $\delta_{c}$ is a complete set of continental fixed effects.

Tables 1-5 analyze the relation between population density in the year $1500 \mathrm{CE}$ and caloric suitability as measured by all the versions of the CSI data. Tables 6-9 extend the analysis to the years 1000CE and $1 \mathrm{CE}$ using only the Average CSI (only productive cells and crops) and (all cells and only productive crops) measures. ${ }^{5}$ All tables have the same structure and show standardized coefficients in order to facilitate comparison across years, measures and specifications.

Table 1 shows the results when suing the pre-1500CE Average CSI (all cells and crops), which penalizes average productivity by including non-productive crops and cells. Column

\footnotetext{
${ }^{5}$ Similar results are obtained if instead the Average CSI (all cells and crops) or the Maximum CSI were employed.
} 


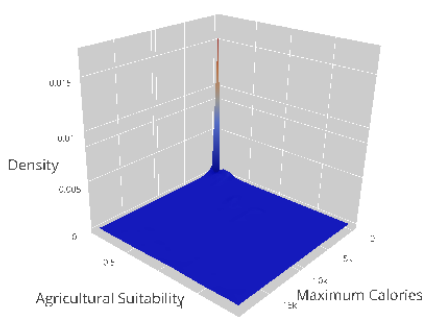

(a)

Post-1500CE Average Calories and Agricultural Suitability

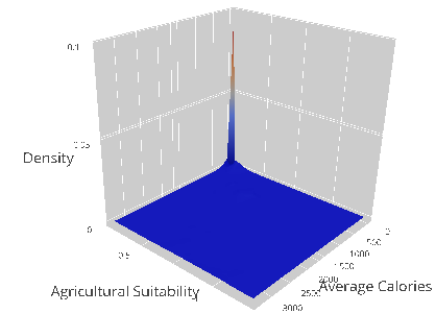

(c)
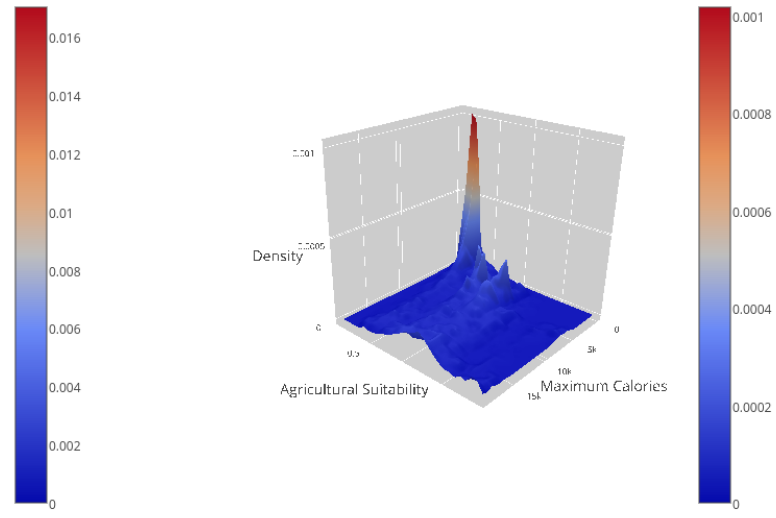

(b)

Post-1500CE Average Calories (No Zeros) and Agricultural Suitability
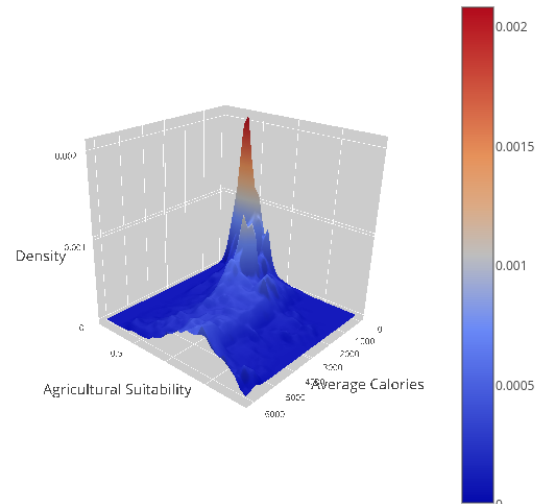

(d)

Figure 9: Joint distribution of agricultural suitability and post-1500CE caloric suitability indices.

(1) accounts for unobservable time invariant factors at the continent level, which might affect population density and be correlated with CSI. The estimated standardized effect of CSI on log population density in $1500 \mathrm{CE}$ is highly statistically and economically significant. In particular, it implies that a 1-standard deviation (SD) increase in CSI generates a 0.5$\mathrm{SD}$ increase in log population density. Furthermore, the semi-partial $R^{2}$ implies that after controlling for the unobservable time invariant factors at the continent level the remaining variation in CSI can explain $13 \%$ of the total variation in log population density in $1500 \mathrm{CE}$. 


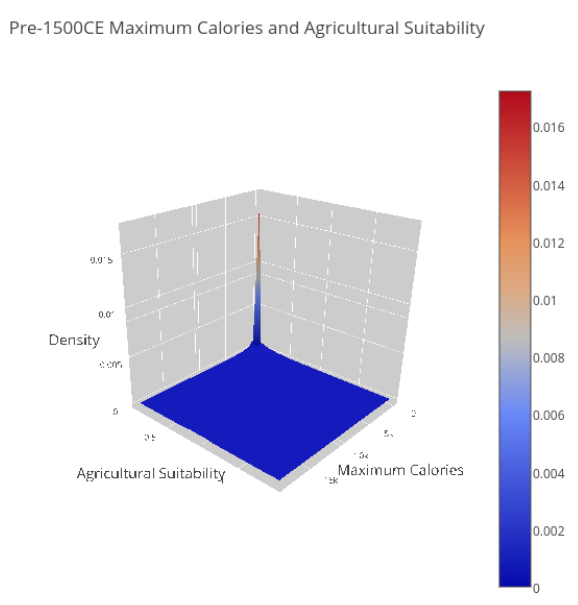

(a)

Pre-1500CE Average Calories and Agricultural Suitability

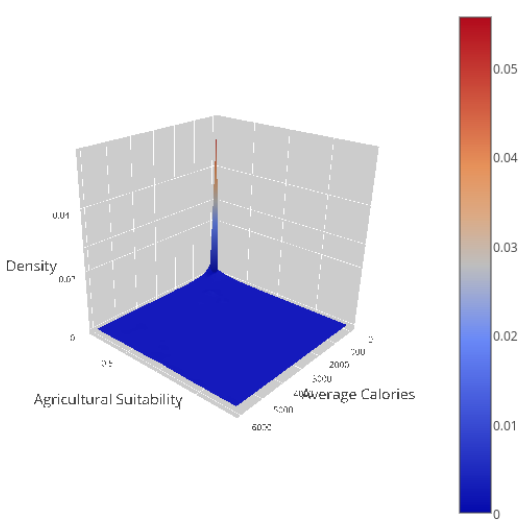

(c)
Pre-1500CE Maximum Average Calories (No Zeros) and Agricultural Suitability
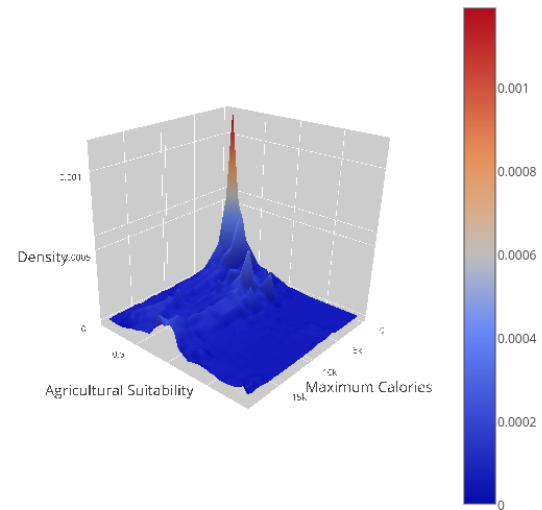

(b)

Pre-1500CE Average Calories (No Zeros) and Agricultural Suitability
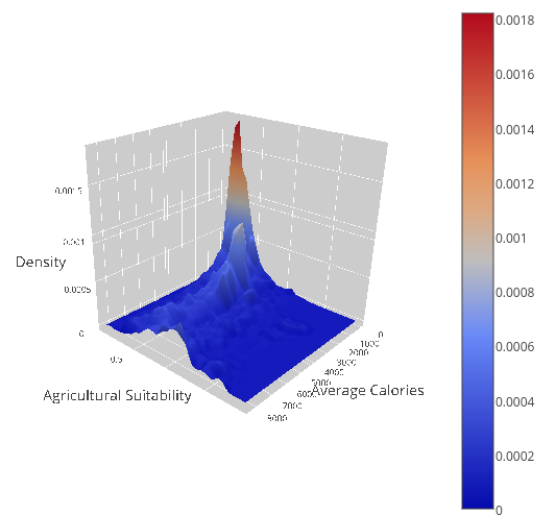

(d)

Figure 10: Joint distribution of pre-1500CE Caloric Suitability Indices and Agricultural Suitability.

Column (2) additionally accounts for the effect of geography, by controlling for the country's absolute latitude, its share of land within 100kms of sea, its average elevation above sea level, its level of ruggedness, its average yearly temperature, its average yearly precipitation, and for it being landlocked or an island. The estimated effect of caloric suitability remains economically and statistically significant and implies that 1-SD increase in CSI generates a 0.46-SD increase in log population density. Furthermore, the variation in CSI that is orthogonal to these geographical factors and continental fixed effects still explains a $9 \%$ of the 


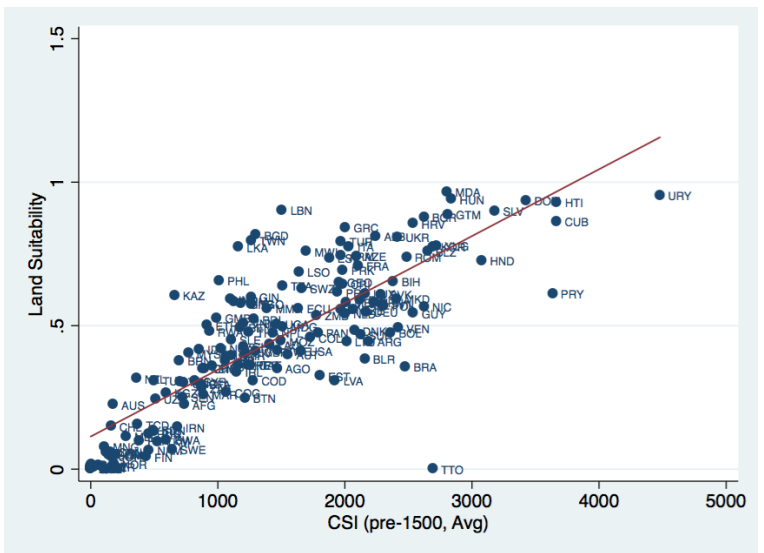

(a)

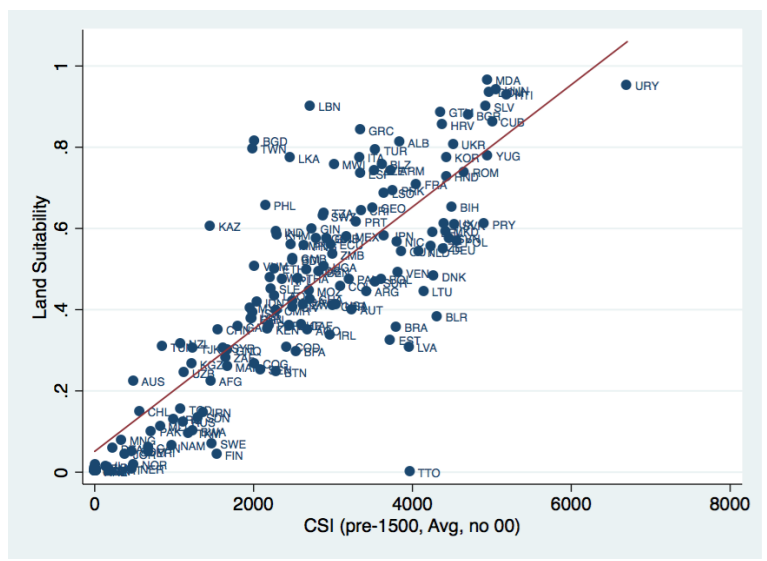

(c)

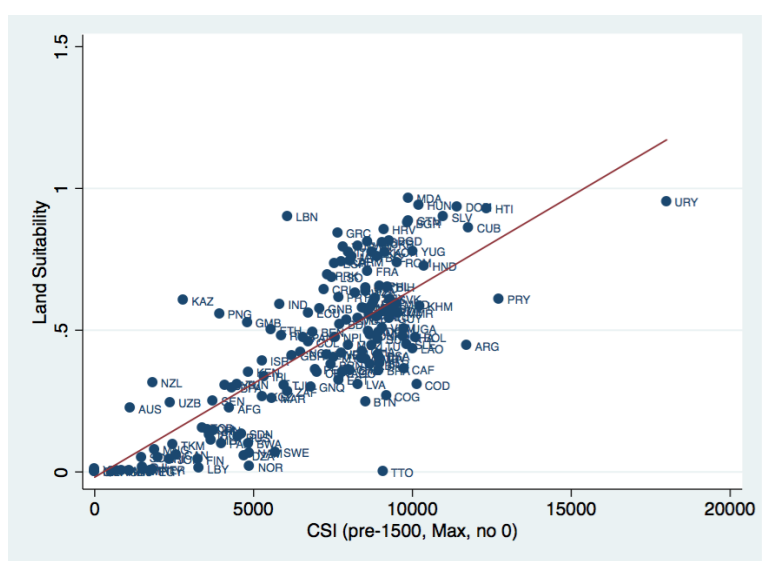

(e)

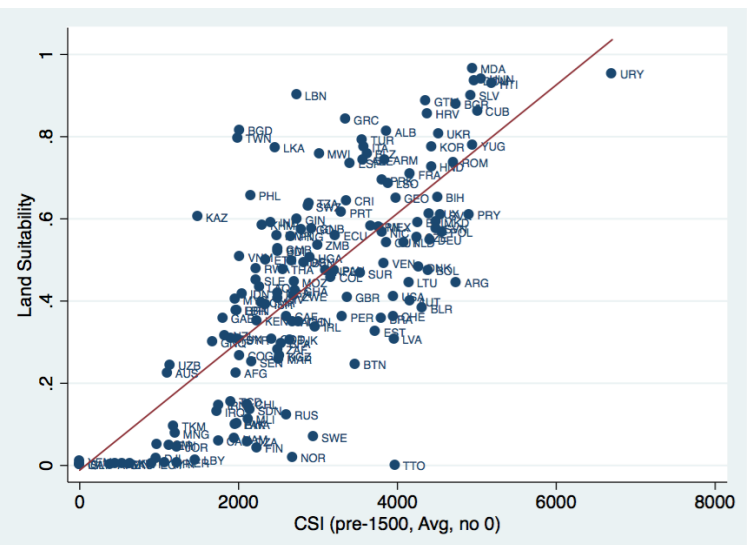

(b)

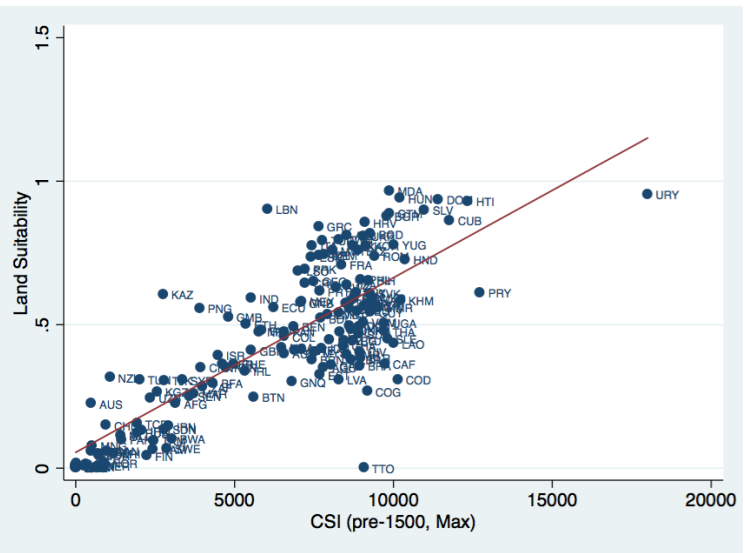

(d)

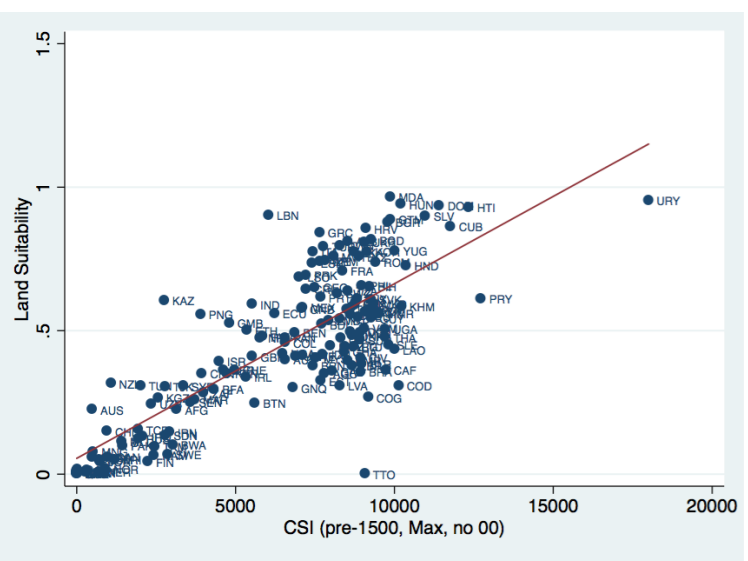

(f)

Figure 11: Country-Level Measures of pre-1500CE Caloric Suitability Indices and Agricultural Suitability. 
total variation in log population density.

Column (3) accounts for the number of years since transition to agriculture (YST), which has been proposed as a major determinant of pre-colonial development (Diamond, 1997). This decreases the sample size by 22 countries to 160 . The standardized coefficient of the Neolithic transition implies that increasing the number of years since the emergence of agriculture by 1-SD increases log population density by 0.5 -SD. The coefficient on CSI decreases to 0.38 , but remains statistically significant at the $1 \%$ level. The semi-partial $R^{2}$ of both variables is $6 \%$. Column (4) replicates the analysis of column (3) on the sample for which agricultural suitability data is available. Notice that the sample size falls by another 9 countries due to missing data. Still, the coefficients on CSI and YST remain basically unchanged.

Columns (5)-(7) include the various versions of the agricultural suitability index into the analysis. In the horse race between CSI and ASI, the estimated effect of CSI remains economically and statistically significant, while the effect of ASI is always close to zero and not statistically significant. Furthermore, as the semi-partial $R^{2}$ shows, the ASI does not have any explanatory power once CSI is included in the analysis. On the other hand, although diminished, CSI retains its explanatory power even after controlling for agricultural suitability.

Table 2 uses the Average pre-1500 CSI (only productive cells and crops) measure which excludes non-productive cells and crops. As can be seen there, the estimated effect of CSI on log population density in 1500CE is even larger than before. Furthermore, in all specifications the variation that is specific to caloric suitability is higher than in the previous table. This results is reassuring since the exclusion of non-productive crops and cells in the Average CSI (only productive cells and crops) should better capture the possibilities for sustaining human life. Inclusion of non-productive cells while excluding non-productive crops, Average CSI (all cells and only productive crops), generates similar results as shown in table 3. Additionally, as tables 4 and 5 show that the results also hold if one uses the Maximum CSI.

Finally, tables 6-9 show that these results also hold for the year $1000 \mathrm{CE}$ and $1 \mathrm{CE}$. The estimates suggest that caloric suitability has played an important role in the determination of the differential population densities across countries. Furthermore, the estimates suggest that 1-SD increase in caloric suitability increased log population density between 0.3-0.5 standard deviations, which is a non-negligible effect.

\section{Conclusion}

This paper introduced novel indices of land productivity based on the Caloric Suitability In-

dex (CSI)Galor and Özak (2014). It established that the CSI dominates the commonly used 
Table 1: Pre-1500CE Caloric Suitability Index (Average, all cells and crops) and Population Density (1500CE)

\begin{tabular}{|c|c|c|c|c|c|c|c|}
\hline & \multicolumn{7}{|c|}{ Log Population Density (1500CE) } \\
\hline & \multicolumn{3}{|c|}{ Full Sample } & \multicolumn{4}{|c|}{ Suitability Sample } \\
\hline & (1) & $(2)$ & (3) & (4) & (5) & (6) & (7) \\
\hline CSI (pre-1500, Avg) & $\begin{array}{l}0.50^{* * *} \\
(0.10)\end{array}$ & $\begin{array}{l}0.46^{* * *} \\
(0.10)\end{array}$ & $\begin{array}{l}0.38^{* * *} \\
(0.09)\end{array}$ & $\begin{array}{l}0.35^{* * *} \\
(0.09)\end{array}$ & $\begin{array}{l}0.29^{*} \\
(0.15)\end{array}$ & $\begin{array}{l}0.27^{* *} \\
(0.12)\end{array}$ & $\begin{array}{l}0.32^{* * *} \\
(0.11)\end{array}$ \\
\hline $\begin{array}{l}\text { Neolithic Transition } \\
\text { Timing }\end{array}$ & & & $\begin{array}{l}0.50^{* * *} \\
(0.11)\end{array}$ & $\begin{array}{l}0.46^{* * *} \\
(0.11)\end{array}$ & $\begin{array}{l}0.46^{* * *} \\
(0.11)\end{array}$ & $\begin{array}{l}0.48^{* * *} \\
(0.12)\end{array}$ & $\begin{array}{l}0.46^{* * *} \\
(0.11)\end{array}$ \\
\hline Land Suitability & & & & & $\begin{array}{l}0.06 \\
(0.12)\end{array}$ & & \\
\hline $\begin{array}{l}\text { Land Suitability } \\
\text { (Climate) }\end{array}$ & & & & & & $\begin{array}{l}0.11 \\
(0.10)\end{array}$ & \\
\hline $\begin{array}{l}\text { Land Suitability } \\
\text { (Soil) }\end{array}$ & & & & & & & $\begin{array}{l}0.05 \\
(0.08)\end{array}$ \\
\hline
\end{tabular}

\begin{tabular}{|c|c|c|c|c|c|c|c|}
\hline \multirow[b]{3}{*}{ CSI (pre-1500, Avg) } & \multicolumn{7}{|c|}{ Semi-Partial $R^{2}$} \\
\hline & \multicolumn{3}{|c|}{ Full Sample } & \multicolumn{4}{|c|}{ Suitability Sample } \\
\hline & $0.13^{* * *}$ & $0.09^{* * *}$ & $0.06^{* * *}$ & $0.06^{* * *}$ & $0.01^{*}$ & $0.02^{* *}$ & $0.03^{* * *}$ \\
\hline Neolithic Transition Timing & & & $0.06^{* * *}$ & $0.05^{* * *}$ & $0.05^{* * *}$ & $0.06^{* * *}$ & $0.05^{* * *}$ \\
\hline Land Suitability & & & & & 0.00 & & \\
\hline Land Suitability (Climate) & & & & & & 0.00 & \\
\hline Land Suitability (Soil) & & & & & & & 0.00 \\
\hline Continental FE & Yes & Yes & Yes & Yes & Yes & Yes & Yes \\
\hline Geographical Controls & No & Yes & Yes & Yes & Yes & Yes & Yes \\
\hline Adjusted- $R^{2}$ & 0.42 & 0.47 & 0.57 & 0.56 & 0.56 & 0.57 & 0.56 \\
\hline$R^{2}$ & 0.44 & 0.51 & 0.61 & 0.61 & 0.61 & 0.62 & 0.61 \\
\hline Observations & 182 & 182 & 160 & 151 & 151 & 155 & 151 \\
\hline
\end{tabular}

Notes: Geographical controls included in regression are (i) absolute latitude, (ii) share of land within 100kms of sea, (iii) average elevation above sea level, (iv) ruggedness, (v) average temperature, (vi) average precipitation, (vii) landlocked and island dummies. Standardized coefficients with heteroskedasticity robust standard error estimates in parenthesis; *** denotes statistical significance at the $1 \%$ level, ** at the $5 \%$ level, and * at the $10 \%$ level, all for two-sided hypothesis tests.

measure of agricultural suitability in the examination of the effect of land productivity on comparative economic development. The analysis demonstrated that the agricultural suitability index does not capture the large variation in the potential caloric yield across equally suitable land, reflecting the fact that land suitable for agriculture is not necessarily suitable for the most caloric-intensive crops. Hence, in light of the instrumental role played by caloric yield in sustaining and supporting population growth, and given importance of pre-industrial 
Table 2: pre-1500CE Caloric Suitability Index (Average, only productive cells and crops) and Population Density (1500CE)

\begin{tabular}{|c|c|c|c|c|c|c|c|}
\hline & \multicolumn{7}{|c|}{ Log Population Density (1500CE) } \\
\hline & \multicolumn{3}{|c|}{ Full Sample } & \multicolumn{4}{|c|}{ Suitability Sample } \\
\hline & $(1)$ & (2) & $(3)$ & $(4)$ & $(5)$ & (6) & $(7)$ \\
\hline CSI (pre-1500, Avg) & $\begin{array}{l}0.51^{* * *} \\
(0.10)\end{array}$ & $\begin{array}{l}0.54^{* * *} \\
(0.09)\end{array}$ & $\begin{array}{l}0.46^{* * *} \\
(0.09)\end{array}$ & $\begin{array}{l}0.46^{* * *} \\
(0.09)\end{array}$ & $\begin{array}{l}0.48^{* * *} \\
(0.11)\end{array}$ & $\begin{array}{l}0.41^{* * *} \\
(0.10)\end{array}$ & $\begin{array}{l}0.45^{* * *} \\
(0.10)\end{array}$ \\
\hline $\begin{array}{l}\text { Neolithic Transition } \\
\text { Timing }\end{array}$ & & & $\begin{array}{l}0.50^{* * *} \\
(0.11)\end{array}$ & $\begin{array}{l}0.46^{* * *} \\
(0.10)\end{array}$ & $\begin{array}{l}0.46^{* * *} \\
(0.11)\end{array}$ & $\begin{array}{l}0.47^{* * *} \\
(0.11)\end{array}$ & $\begin{array}{l}0.46^{* * *} \\
(0.10)\end{array}$ \\
\hline Land Suitability & & & & & $\begin{array}{l}-0.02 \\
(0.09)\end{array}$ & & \\
\hline $\begin{array}{l}\text { Land Suitability } \\
\text { (Climate) }\end{array}$ & & & & & & $\begin{array}{l}0.06 \\
(0.08)\end{array}$ & \\
\hline $\begin{array}{l}\text { Land Suitability } \\
\text { (Soil) }\end{array}$ & & & & & & & $\begin{array}{l}0.01 \\
(0.08)\end{array}$ \\
\hline
\end{tabular}

\begin{tabular}{|c|c|c|c|c|c|c|c|}
\hline \multirow[b]{3}{*}{ CSI (pre-1500, Avg) } & \multicolumn{7}{|c|}{ Semi-Partial $R^{2}$} \\
\hline & \multicolumn{3}{|c|}{ Full Sample } & \multicolumn{4}{|c|}{ Suitability Sample } \\
\hline & $0.13^{* * *}$ & $0.12^{* * *}$ & $0.09^{* * *}$ & $0.09^{* * *}$ & $0.04^{* * *}$ & $0.04^{* * *}$ & $0.06^{* * *}$ \\
\hline Neolithic Transition Timing & & & $0.06^{* * *}$ & $0.05^{* * *}$ & $0.05^{* * *}$ & $0.05^{* * *}$ & $0.05^{* * *}$ \\
\hline Land Suitability & & & & & 0.00 & & \\
\hline Land Suitability (Climate) & & & & & & 0.00 & \\
\hline Land Suitability (Soil) & & & & & & & 0.00 \\
\hline Continental FE & Yes & Yes & Yes & Yes & Yes & Yes & Yes \\
\hline Geographical Controls & No & Yes & Yes & Yes & Yes & Yes & Yes \\
\hline Adjusted- $R^{2}$ & 0.42 & 0.50 & 0.59 & 0.60 & 0.59 & 0.60 & 0.59 \\
\hline$R^{2}$ & 0.44 & 0.54 & 0.63 & 0.64 & 0.64 & 0.64 & 0.64 \\
\hline Observations & 182 & 182 & 160 & 151 & 151 & 155 & 151 \\
\hline
\end{tabular}

Notes: Geographical controls included in regression are (i) absolute latitude, (ii) share of land within 100kms of sea, (iii) average elevation above sea level, (iv) ruggedness, (v) average temperature, (vi) average precipitation, (vii) landlocked and island dummies. Standardized coefficients with heteroskedasticity robust standard error estimates in parenthesis; *** denotes statistical significance at the $1 \%$ level, ** at the $5 \%$ level, and * at the $10 \%$ level, all for two-sided hypothesis tests.

population density for the subsequent course of economic development, the Caloric Suitability Index dominates the conventional measure in capturing the effect of land productivity on pre-colonial population density and the subsequent course of economic development. 
Table 3: Pre-1500CE Caloric Suitability Index (Average, all cells and only productive crops) and Population Density (1500CE)

\begin{tabular}{|c|c|c|c|c|c|c|c|}
\hline & \multicolumn{7}{|c|}{ Log Population Density (1500CE) } \\
\hline & \multicolumn{3}{|c|}{ Full Sample } & \multicolumn{4}{|c|}{ Suitability Sample } \\
\hline & $(1)$ & $(2)$ & $(3)$ & $(4)$ & $(5)$ & (6) & $(7)$ \\
\hline CSI (pre-1500, Avg) & $\begin{array}{l}0.57^{* * *} \\
(0.09)\end{array}$ & $\begin{array}{l}0.55^{* * *} \\
(0.09)\end{array}$ & $\begin{array}{l}0.44^{* * *} \\
(0.08)\end{array}$ & $\begin{array}{l}0.43^{* * *} \\
(0.09)\end{array}$ & $\begin{array}{l}0.51^{* * *} \\
(0.12)\end{array}$ & $\begin{array}{l}0.43^{* * *} \\
(0.10)\end{array}$ & $\begin{array}{l}0.43^{* * *} \\
(0.10)\end{array}$ \\
\hline $\begin{array}{l}\text { Neolithic Transition } \\
\text { Timing }\end{array}$ & & & $\begin{array}{l}0.47^{* * *} \\
(0.11)\end{array}$ & $\begin{array}{l}0.44^{* * *} \\
(0.11)\end{array}$ & $\begin{array}{l}0.45^{* * *} \\
(0.11)\end{array}$ & $\begin{array}{l}0.46^{* * *} \\
(0.11)\end{array}$ & $\begin{array}{l}0.44^{* * *} \\
(0.11)\end{array}$ \\
\hline Land Suitability & & & & & $\begin{array}{l}-0.09 \\
(0.10)\end{array}$ & & \\
\hline $\begin{array}{l}\text { Land Suitability } \\
\text { (Climate) }\end{array}$ & & & & & & $\begin{array}{l}-0.01 \\
(0.09)\end{array}$ & \\
\hline $\begin{array}{l}\text { Land Suitability } \\
\text { (Soil) }\end{array}$ & & & & & & & $\begin{array}{l}-0.01 \\
(0.08)\end{array}$ \\
\hline
\end{tabular}

\begin{tabular}{|c|c|c|c|c|c|c|c|}
\hline \multirow[b]{3}{*}{ CSI (pre-1500, Avg) } & \multicolumn{7}{|c|}{ Semi-Partial $R^{2}$} \\
\hline & \multicolumn{3}{|c|}{ Full Sample } & \multicolumn{4}{|c|}{ Suitability Sample } \\
\hline & $0.17^{* * *}$ & $0.14^{* * *}$ & $0.09^{* * *}$ & $0.08^{* * *}$ & $0.04^{* * *}$ & $0.04^{* * *}$ & $0.06^{* * *}$ \\
\hline Neolithic Transition Timing & & & $0.05^{* * *}$ & $0.05^{* * *}$ & $0.05^{* * *}$ & $0.05^{* * *}$ & $0.05^{* * *}$ \\
\hline Land Suitability & & & & & 0.00 & & \\
\hline Land Suitability (Climate) & & & & & & 0.00 & \\
\hline Land Suitability (Soil) & & & & & & & 0.00 \\
\hline Continental FE & Yes & Yes & Yes & Yes & Yes & Yes & Yes \\
\hline Geographical Controls & No & Yes & Yes & Yes & Yes & Yes & Yes \\
\hline Adjusted- $R^{2}$ & 0.47 & 0.52 & 0.59 & 0.59 & 0.59 & 0.59 & 0.59 \\
\hline$R^{2}$ & 0.49 & 0.56 & 0.64 & 0.64 & 0.64 & 0.64 & 0.64 \\
\hline Observations & 182 & 182 & 160 & 151 & 151 & 155 & 151 \\
\hline
\end{tabular}

Notes: Geographical controls included in regression are (i) absolute latitude, (ii) share of land within 100kms of sea, (iii) average elevation above sea level, (iv) ruggedness, (v) average temperature, (vi) average precipitation, (vii) landlocked and island dummies. Standardized coefficients with heteroskedasticity robust standard error estimates in parenthesis; *** denotes statistical significance at the $1 \%$ level, $* *$ at the $5 \%$ level, and * at the $10 \%$ level, all for two-sided hypothesis tests. 
Table 4: Pre-1500CE Caloric Suitability Index (Maximum, all cells and crops) and Population Density (1500CE)

\begin{tabular}{|c|c|c|c|c|c|c|c|}
\hline & \multicolumn{7}{|c|}{ Log Population Density (1500CE) } \\
\hline & \multicolumn{3}{|c|}{ Full Sample } & \multicolumn{4}{|c|}{ Suitability Sample } \\
\hline & (1) & $(2)$ & $(3)$ & (4) & $(5)$ & (6) & (7) \\
\hline CSI (pre-1500, Max) & $\begin{array}{l}0.47^{* * *} \\
(0.09)\end{array}$ & $\begin{array}{l}0.44^{* * *} \\
(0.09)\end{array}$ & $\begin{array}{l}0.34^{* * *} \\
(0.10)\end{array}$ & $\begin{array}{l}0.32^{* * *} \\
(0.10)\end{array}$ & $\begin{array}{l}0.22 \\
(0.14)\end{array}$ & $\begin{array}{l}0.23^{*} \\
(0.14)\end{array}$ & $\begin{array}{l}0.26^{* *} \\
(0.11)\end{array}$ \\
\hline $\begin{array}{l}\text { Neolithic Transition } \\
\text { Timing }\end{array}$ & & & $\begin{array}{l}0.50^{* * *} \\
(0.11)\end{array}$ & $\begin{array}{l}0.47^{* * *} \\
(0.11)\end{array}$ & $\begin{array}{l}0.45^{* * *} \\
(0.12)\end{array}$ & $\begin{array}{l}0.48^{* * *} \\
(0.12)\end{array}$ & $\begin{array}{l}0.46^{* * *} \\
(0.11)\end{array}$ \\
\hline Land Suitability & & & & & $\begin{array}{l}0.12 \\
(0.10)\end{array}$ & & \\
\hline $\begin{array}{l}\text { Land Suitability } \\
\text { (Climate) }\end{array}$ & & & & & & $\begin{array}{l}0.13 \\
(0.11)\end{array}$ & \\
\hline $\begin{array}{l}\text { Land Suitability } \\
\text { (Soil) }\end{array}$ & & & & & & & $\begin{array}{l}0.09 \\
(0.08)\end{array}$ \\
\hline & \multicolumn{7}{|c|}{ Semi-Partial $R^{2}$} \\
\hline & \multicolumn{3}{|c|}{ Full Sample } & \multicolumn{4}{|c|}{ Suitability Sample } \\
\hline CSI (pre-1500, Max) & $0.15^{* * *}$ & $0.10^{* * *}$ & $0.06^{* * *}$ & $0.05 * * *$ & 0.01 & $0.01^{*}$ & $0.02^{* *}$ \\
\hline Neolithic Transition Timing & & & $0.06^{* * *}$ & $0.06^{* * *}$ & $0.05^{* * *}$ & $0.05^{* * *}$ & $0.05^{* * *}$ \\
\hline Land Suitability & & & & & 0.00 & & \\
\hline Land Suitability (Climate) & & & & & & 0.00 & \\
\hline Land Suitability (Soil) & & & & & & & 0.00 \\
\hline Continental FE & Yes & Yes & Yes & Yes & Yes & Yes & Yes \\
\hline Geographical Controls & No & Yes & Yes & Yes & Yes & Yes & Yes \\
\hline Adjusted- $R^{2}$ & 0.44 & 0.48 & 0.56 & 0.55 & 0.56 & 0.56 & 0.56 \\
\hline$R^{2}$ & 0.46 & 0.52 & 0.60 & 0.60 & 0.61 & 0.61 & 0.61 \\
\hline Observations & 182 & 182 & 160 & 151 & 151 & 155 & 151 \\
\hline
\end{tabular}

Notes: Geographical controls included in regression are (i) absolute latitude, (ii) share of land within 100kms of sea, (iii) average elevation above sea level, (iv) ruggedness, (v) average temperature, (vi) average precipitation, (vii) landlocked and island dummies. Standardized coefficients with heteroskedasticity robust standard error estimates in parenthesis; $* * *$ denotes statistical significance at the $1 \%$ level, ${ }^{* *}$ at the $5 \%$ level, and * at the $10 \%$ level, all for two-sided hypothesis tests. 
Table 5: Pre-1500CE Caloric Suitability Index (Maximum, only productive cells and crops) and Population Density (1500CE)

\begin{tabular}{|c|c|c|c|c|c|c|c|}
\hline & \multicolumn{7}{|c|}{ Log Population Density (1500CE) } \\
\hline & \multicolumn{3}{|c|}{ Full Sample } & \multicolumn{4}{|c|}{ Suitability Sample } \\
\hline & (1) & $(2)$ & $(3)$ & $(4)$ & (5) & (6) & $(7)$ \\
\hline CSI (pre-1500, Max) & $\begin{array}{l}0.43^{* * *} \\
(0.09)\end{array}$ & $\begin{array}{l}0.41^{* * *} \\
(0.09)\end{array}$ & $\begin{array}{l}0.32^{* * *} \\
(0.10)\end{array}$ & $\begin{array}{l}0.30^{* * *} \\
(0.10)\end{array}$ & $\begin{array}{l}0.20 \\
(0.12)\end{array}$ & $\begin{array}{l}0.21^{*} \\
(0.12)\end{array}$ & $\begin{array}{l}0.24^{* *} \\
(0.10)\end{array}$ \\
\hline $\begin{array}{l}\text { Neolithic Transition } \\
\text { Timing }\end{array}$ & & & $\begin{array}{l}0.52^{* * *} \\
(0.11)\end{array}$ & $\begin{array}{l}0.49^{* * *} \\
(0.11)\end{array}$ & $\begin{array}{l}0.46^{* * *} \\
(0.11)\end{array}$ & $\begin{array}{l}0.48^{* * *} \\
(0.11)\end{array}$ & $\begin{array}{l}0.48^{* * *} \\
(0.11)\end{array}$ \\
\hline Land Suitability & & & & & $\begin{array}{l}0.14 \\
(0.10)\end{array}$ & & \\
\hline $\begin{array}{l}\text { Land Suitability } \\
\text { (Climate) }\end{array}$ & & & & & & $\begin{array}{l}0.16 \\
(0.10)\end{array}$ & \\
\hline $\begin{array}{l}\text { Land Suitability } \\
\text { (Soil) }\end{array}$ & & & & & & & $\begin{array}{l}0.11 \\
(0.08)\end{array}$ \\
\hline
\end{tabular}

\begin{tabular}{|c|c|c|c|c|c|c|c|}
\hline \multirow[b]{3}{*}{ CSI (pre-1500, Max) } & \multicolumn{7}{|c|}{ Semi-Partial $R^{2}$} \\
\hline & \multicolumn{3}{|c|}{ Full Sample } & \multicolumn{4}{|c|}{ Suitability Sample } \\
\hline & $0.12^{* * *}$ & $0.09^{* * *}$ & $0.05^{* * *}$ & $0.05^{* * *}$ & 0.01 & $0.01^{*}$ & $0.02^{* *}$ \\
\hline Neolithic Transition Timing & & & $0.07 * * *$ & $0.06^{* * *}$ & $0.05^{* * *}$ & $0.06^{* * *}$ & $0.06^{* * *}$ \\
\hline Land Suitability & & & & & 0.01 & & \\
\hline Land Suitability (Climate) & & & & & & 0.01 & \\
\hline Land Suitability (Soil) & & & & & & & 0.00 \\
\hline Continental FE & Yes & Yes & Yes & Yes & Yes & Yes & Yes \\
\hline Geographical Controls & No & Yes & Yes & Yes & Yes & Yes & Yes \\
\hline Adjusted- $R^{2}$ & 0.41 & 0.46 & 0.56 & 0.55 & 0.56 & 0.56 & 0.55 \\
\hline$R^{2}$ & 0.43 & 0.51 & 0.60 & 0.60 & 0.61 & 0.61 & 0.60 \\
\hline Observations & 182 & 182 & 160 & 151 & 151 & 155 & 151 \\
\hline
\end{tabular}

Notes: Geographical controls included in regression are (i) absolute latitude, (ii) share of land within 100kms of sea, (iii) average elevation above sea level, (iv) ruggedness, (v) average temperature, (vi) average precipitation, (vii) landlocked and island dummies. Standardized coefficients with heteroskedasticity robust standard error estimates in parenthesis; *** denotes statistical significance at the $1 \%$ level, ** at the $5 \%$ level, and * at the $10 \%$ level, all for two-sided hypothesis tests. 
Table 6: Pre-1500CE Caloric Suitability Index (Average, only productive cells and crops) and Population Density (1000CE)

\begin{tabular}{|c|c|c|c|c|c|c|c|}
\hline & \multicolumn{7}{|c|}{ Log Population Density (1000CE) } \\
\hline & \multicolumn{3}{|c|}{ Full Sample } & \multicolumn{4}{|c|}{ Suitability Sample } \\
\hline & $(1)$ & $(2)$ & $(3)$ & $(4)$ & $(5)$ & (6) & $(7)$ \\
\hline CSI (pre-1500, Avg) & $\begin{array}{l}0.50 * * * \\
(0.09)\end{array}$ & $\begin{array}{l}0.52^{* * *} \\
(0.08)\end{array}$ & $\begin{array}{l}0.44^{* * *} \\
(0.08)\end{array}$ & $\begin{array}{l}0.43^{* * *} \\
(0.08)\end{array}$ & $\begin{array}{l}0.42^{* * *} \\
(0.11)\end{array}$ & $\begin{array}{l}0.40^{* * *} \\
(0.09)\end{array}$ & $\begin{array}{l}0.40^{* * *} \\
(0.10)\end{array}$ \\
\hline $\begin{array}{l}\text { Neolithic Transition } \\
\text { Timing }\end{array}$ & & & $\begin{array}{l}0.54^{* * *} \\
(0.11)\end{array}$ & $\begin{array}{l}0.50^{* * *} \\
(0.11)\end{array}$ & $\begin{array}{l}0.50^{* * *} \\
(0.12)\end{array}$ & $\begin{array}{l}0.52^{\text {*** }} \\
(0.12)\end{array}$ & $\begin{array}{l}0.50^{* * *} \\
(0.11)\end{array}$ \\
\hline Land Suitability & & & & & $\begin{array}{l}0.01 \\
(0.09)\end{array}$ & & \\
\hline $\begin{array}{l}\text { Land Suitability } \\
\text { (Climate) }\end{array}$ & & & & & & $\begin{array}{l}0.03 \\
(0.08)\end{array}$ & \\
\hline $\begin{array}{l}\text { Land Suitability } \\
\text { (Soil) }\end{array}$ & & & & & & & $\begin{array}{l}0.04 \\
(0.08)\end{array}$ \\
\hline
\end{tabular}

\begin{tabular}{|c|c|c|c|c|c|c|c|}
\hline \multirow[b]{3}{*}{ CSI (pre-1500, Avg) } & \multicolumn{7}{|c|}{ Semi-Partial $R^{2}$} \\
\hline & \multicolumn{3}{|c|}{ Full Sample } & \multicolumn{4}{|c|}{ Suitability Sample } \\
\hline & $0.12^{* * *}$ & $0.11^{* * *}$ & $0.07 * * *$ & $0.08^{* * *}$ & $0.03^{* * *}$ & $0.04^{* * *}$ & $0.05^{* * *}$ \\
\hline Neolithic Transition Timing & & & $0.07 * * *$ & $0.06^{* * *}$ & $0.06^{* * *}$ & $0.07^{* * *}$ & $0.06^{* * *}$ \\
\hline Land Suitability & & & & & 0.00 & & \\
\hline Land Suitability (Climate) & & & & & & 0.00 & \\
\hline Land Suitability (Soil) & & & & & & & 0.00 \\
\hline Continental FE & Yes & Yes & Yes & Yes & Yes & Yes & Yes \\
\hline Geographical Controls & No & Yes & Yes & Yes & Yes & Yes & Yes \\
\hline Adjusted- $R^{2}$ & 0.42 & 0.49 & 0.60 & 0.60 & 0.60 & 0.60 & 0.60 \\
\hline$R^{2}$ & 0.44 & 0.53 & 0.64 & 0.64 & 0.64 & 0.65 & 0.64 \\
\hline Observations & 175 & 175 & 154 & 146 & 146 & 149 & 146 \\
\hline
\end{tabular}

Notes: Geographical controls included in regression are (i) absolute latitude, (ii) share of land within 100kms of sea, (iii) average elevation above sea level, (iv) ruggedness, (v) average temperature, (vi) average precipitation, (vii) landlocked and island dummies. Standardized coefficients with heteroskedasticity robust standard error estimates in parenthesis; *** denotes statistical significance at the $1 \%$ level, ** at the $5 \%$ level, and * at the $10 \%$ level, all for two-sided hypothesis tests. 
Table 7: Pre-1500CE Caloric Suitability Index (Average, all cells and only productive crops) and Population Density (1000CE)

\begin{tabular}{|c|c|c|c|c|c|c|c|}
\hline & \multicolumn{7}{|c|}{ Log Population Density (1000CE) } \\
\hline & \multicolumn{3}{|c|}{ Full Sample } & \multicolumn{4}{|c|}{ Suitability Sample } \\
\hline & $(1)$ & $(2)$ & $(3)$ & $(4)$ & $(5)$ & $(6)$ & $(7)$ \\
\hline CSI (pre-1500, Avg) & $\begin{array}{l}0.55^{* * *} \\
(0.08)\end{array}$ & $\begin{array}{l}0.53^{* * *} \\
(0.08)\end{array}$ & $\begin{array}{l}0.42^{* * *} \\
(0.07)\end{array}$ & $\begin{array}{l}0.40^{* * *} \\
(0.07)\end{array}$ & $\begin{array}{l}0.45 * * * \\
(0.11)\end{array}$ & $\begin{array}{l}0.43^{* * *} \\
(0.09)\end{array}$ & $\begin{array}{l}0.39^{* * *} \\
(0.09)\end{array}$ \\
\hline $\begin{array}{l}\text { Neolithic Transition } \\
\text { Timing }\end{array}$ & & & $\begin{array}{l}0.52^{* * *} \\
(0.12)\end{array}$ & $\begin{array}{l}0.48^{* * *} \\
(0.12)\end{array}$ & $\begin{array}{l}0.48^{* * *} \\
(0.12)\end{array}$ & $\begin{array}{l}0.51^{* * *} \\
(0.12)\end{array}$ & $\begin{array}{l}0.48^{* * *} \\
(0.12)\end{array}$ \\
\hline Land Suitability & & & & & $\begin{array}{l}-0.05 \\
(0.10)\end{array}$ & & \\
\hline $\begin{array}{l}\text { Land Suitability } \\
\text { (Climate) }\end{array}$ & & & & & & $\begin{array}{l}-0.05 \\
(0.09)\end{array}$ & \\
\hline $\begin{array}{l}\text { Land Suitability } \\
\text { (Soil) }\end{array}$ & & & & & & & $\begin{array}{l}0.02 \\
(0.08)\end{array}$ \\
\hline
\end{tabular}

\begin{tabular}{|c|c|c|c|c|c|c|c|}
\hline \multirow[b]{3}{*}{ CSI (pre-1500, Avg) } & \multicolumn{7}{|c|}{ Semi-Partial $R^{2}$} \\
\hline & \multicolumn{3}{|c|}{ Full Sample } & \multicolumn{4}{|c|}{ Suitability Sample } \\
\hline & $0.16^{* * *}$ & $0.12^{* * *}$ & $0.08^{* * *}$ & $0.08^{* * *}$ & $0.04^{* * *}$ & $0.04^{* * *}$ & $0.05^{* * *}$ \\
\hline Neolithic Transition Timing & & & $0.07 * * *$ & $0.06^{* * *}$ & $0.06^{* * *}$ & $0.06^{* * *}$ & $0.06^{* * *}$ \\
\hline Land Suitability & & & & & 0.00 & & \\
\hline Land Suitability (Climate) & & & & & & 0.00 & \\
\hline Land Suitability (Soil) & & & & & & & 0.00 \\
\hline Continental FE & Yes & Yes & Yes & Yes & Yes & Yes & Yes \\
\hline Geographical Controls & No & Yes & Yes & Yes & Yes & Yes & Yes \\
\hline Continental FE & Yes & Yes & Yes & Yes & Yes & Yes & Yes \\
\hline Geographical Controls & No & Yes & Yes & Yes & Yes & Yes & Yes \\
\hline Adjusted- $R^{2}$ & 0.47 & 0.51 & 0.60 & 0.60 & 0.60 & 0.60 & 0.59 \\
\hline$R^{2}$ & 0.49 & 0.55 & 0.64 & 0.64 & 0.64 & 0.65 & 0.64 \\
\hline Observations & 175 & 175 & 154 & 146 & 146 & 149 & 146 \\
\hline
\end{tabular}

Notes: Geographical controls included in regression are (i) absolute latitude, (ii) share of land within 100kms of sea, (iii) average elevation above sea level, (iv) ruggedness, (v) average temperature, (vi) average precipitation, (vii) landlocked and island dummies. Standardized coefficients with heteroskedasticity robust standard error estimates in parenthesis; *** denotes statistical significance at the $1 \%$ level, $* *$ at the $5 \%$ level, and * at the $10 \%$ level, all for two-sided hypothesis tests. 
Table 8: Pre-1500CE Caloric Suitability Index (Average, only productive cells and crops) and Population Density (1CE)

\begin{tabular}{|c|c|c|c|c|c|c|c|}
\hline & \multicolumn{7}{|c|}{ Log Population Density (1CE) } \\
\hline & \multicolumn{3}{|c|}{ Full Sample } & \multicolumn{4}{|c|}{ Suitability Sample } \\
\hline & (1) & $(2)$ & (3) & (4) & (5) & $(6)$ & $(7)$ \\
\hline CSI (pre-1500, Avg) & $\begin{array}{l}0.40^{* * *} \\
(0.09)\end{array}$ & $\begin{array}{l}0.38^{* * *} \\
(0.09)\end{array}$ & $\begin{array}{l}0.32^{* * *} \\
(0.08)\end{array}$ & $\begin{array}{l}0.31^{* * *} \\
(0.08)\end{array}$ & $\begin{array}{l}0.32^{* * *} \\
(0.09)\end{array}$ & $\begin{array}{l}0.31^{* * *} \\
(0.08)\end{array}$ & $\begin{array}{l}0.26^{* * *} \\
(0.08)\end{array}$ \\
\hline $\begin{array}{l}\text { Neolithic Transition } \\
\text { Timing }\end{array}$ & & & $\begin{array}{l}0.63^{* * *} \\
(0.11)\end{array}$ & $\begin{array}{l}0.62^{* * *} \\
(0.10)\end{array}$ & $\begin{array}{l}0.62^{* * *} \\
(0.11)\end{array}$ & $\begin{array}{l}0.63^{* * *} \\
(0.11)\end{array}$ & $\begin{array}{l}0.61^{* * *} \\
(0.10)\end{array}$ \\
\hline Land Suitability & & & & & $\begin{array}{l}-0.01 \\
(0.08)\end{array}$ & & \\
\hline $\begin{array}{l}\text { Land Suitability } \\
\text { (Climate) }\end{array}$ & & & & & & $\begin{array}{l}0.01 \\
(0.07)\end{array}$ & \\
\hline $\begin{array}{l}\text { Land Suitability } \\
\text { (Soil) }\end{array}$ & & & & & & & $\begin{array}{l}0.08 \\
(0.08)\end{array}$ \\
\hline & \multicolumn{7}{|c|}{ Semi-Partial $R^{2}$} \\
\hline & \multicolumn{3}{|c|}{ Full Sample } & \multicolumn{4}{|c|}{ Suitability Sample } \\
\hline CSI (pre-1500, Avg) & $0.08^{* * *}$ & $0.05^{* * *}$ & $0.04^{* * *}$ & $0.04^{* * *}$ & $0.02^{* * *}$ & $0.02^{* * *}$ & $0.02^{* * *}$ \\
\hline $\begin{array}{l}\text { Neolithic Transition Timing } \\
\text { Land Suitability }\end{array}$ & & & $0.10^{* * *}$ & $0.11^{* * *}$ & $\begin{array}{l}0.10^{* * *} \\
0.00\end{array}$ & $0.10^{* * *}$ & $0.10^{* * *}$ \\
\hline Land Suitability (Climate) & & & & & & 0.00 & \\
\hline Land Suitability (Soil) & & & & & & & 0.00 \\
\hline Continental FE & Yes & Yes & Yes & Yes & Yes & Yes & Yes \\
\hline Geographical Controls & No & Yes & Yes & Yes & Yes & Yes & Yes \\
\hline Adjusted- $R^{2}$ & 0.48 & 0.52 & 0.69 & 0.69 & 0.69 & 0.69 & 0.69 \\
\hline$R^{2}$ & 0.50 & 0.57 & 0.73 & 0.73 & 0.73 & 0.73 & 0.73 \\
\hline Observations & 154 & 154 & 136 & 131 & 131 & 133 & 131 \\
\hline
\end{tabular}

Notes: Geographical controls included in regression are (i) absolute latitude, (ii) share of land within 100kms of sea, (iii) average elevation above sea level, (iv) ruggedness, (v) average temperature, (vi) average precipitation, (vii) landlocked and island dummies. Standardized coefficients with heteroskedasticity robust standard error estimates in parenthesis; $* * *$ denotes statistical significance at the $1 \%$ level, ${ }^{* *}$ at the $5 \%$ level, and * at the $10 \%$ level, all for two-sided hypothesis tests. 
Table 9: Pre-1500CE Caloric Suitability Index (Average, all cells and only productive crops) and Population Density (1CE)

\begin{tabular}{|c|c|c|c|c|c|c|c|}
\hline & \multicolumn{7}{|c|}{ Log Population Density (1CE) } \\
\hline & \multicolumn{3}{|c|}{ Full Sample } & \multicolumn{4}{|c|}{ Suitability Sample } \\
\hline & (1) & $(2)$ & $(3)$ & $(4)$ & $(5)$ & $(6)$ & $(7)$ \\
\hline CSI (pre-1500, Avg) & $\begin{array}{l}0.44^{* * *} \\
(0.08)\end{array}$ & $\begin{array}{l}0.38^{* * *} \\
(0.09)\end{array}$ & $\begin{array}{l}0.27 * * * \\
(0.08)\end{array}$ & $\begin{array}{l}0.26 * * * \\
(0.07)\end{array}$ & $\begin{array}{l}0.27 * * * \\
(0.10)\end{array}$ & $\begin{array}{l}0.27^{* * *} \\
(0.08)\end{array}$ & $\begin{array}{l}0.19^{* *} \\
(0.09)\end{array}$ \\
\hline $\begin{array}{l}\text { Neolithic Transition } \\
\text { Timing }\end{array}$ & & & $\begin{array}{l}0.61^{* * *} \\
(0.11)\end{array}$ & $\begin{array}{l}0.60^{* * *} \\
(0.11)\end{array}$ & $\begin{array}{l}0.60^{* * *} \\
(0.11)\end{array}$ & $\begin{array}{l}0.61^{* * *} \\
(0.11)\end{array}$ & $\begin{array}{l}0.59^{* * *} \\
(0.11)\end{array}$ \\
\hline Land Suitability & & & & & $\begin{array}{l}-0.01 \\
(0.09)\end{array}$ & & \\
\hline $\begin{array}{l}\text { Land Suitability } \\
\text { (Climate) }\end{array}$ & & & & & & $\begin{array}{l}-0.01 \\
(0.07)\end{array}$ & \\
\hline $\begin{array}{l}\text { Land Suitability } \\
\text { (Soil) }\end{array}$ & & & & & & & $\begin{array}{l}0.10 \\
(0.08)\end{array}$ \\
\hline
\end{tabular}

\begin{tabular}{|c|c|c|c|c|c|c|c|}
\hline \multirow[b]{3}{*}{ CSI (pre-1500, Avg) } & \multicolumn{7}{|c|}{ Semi-Partial $R^{2}$} \\
\hline & \multicolumn{3}{|c|}{ Full Sample } & \multicolumn{4}{|c|}{ Suitability Sample } \\
\hline & $0.10^{* * *}$ & $0.06^{* * *}$ & $0.03^{* * *}$ & $0.03^{* * *}$ & $0.01^{* * *}$ & $0.02^{* * *}$ & $0.01 * *$ \\
\hline Neolithic Transition Timing & & & $0.10^{* * *}$ & $0.10^{* * *}$ & $0.10^{* * *}$ & $0.10^{* * *}$ & $0.10^{* * *}$ \\
\hline Land Suitability & & & & & 0.00 & & \\
\hline Land Suitability (Climate) & & & & & & 0.00 & \\
\hline Land Suitability (Soil) & & & & & & & 0.00 \\
\hline Continental FE & Yes & Yes & Yes & Yes & Yes & Yes & Yes \\
\hline Geographical Controls & No & Yes & Yes & Yes & Yes & Yes & Yes \\
\hline Continental FE & Yes & Yes & Yes & Yes & Yes & Yes & Yes \\
\hline Geographical Controls & No & Yes & Yes & Yes & Yes & Yes & Yes \\
\hline Adjusted- $R^{2}$ & 0.51 & 0.53 & 0.68 & 0.68 & 0.68 & 0.68 & 0.68 \\
\hline$R^{2}$ & 0.53 & 0.58 & 0.72 & 0.72 & 0.72 & 0.72 & 0.72 \\
\hline Observations & 154 & 154 & 136 & 131 & 131 & 133 & 131 \\
\hline
\end{tabular}

Notes: Geographical controls included in regression are (i) absolute latitude, (ii) share of land within 100kms of sea, (iii) average elevation above sea level, (iv) ruggedness, (v) average temperature, (vi) average precipitation, (vii) landlocked and island dummies. Standardized coefficients with heteroskedasticity robust standard error estimates in parenthesis; *** denotes statistical significance at the $1 \%$ level, $* *$ at the $5 \%$ level, and * at the $10 \%$ level, all for two-sided hypothesis tests. 


\section{A Download Options for Caloric Suitability Indices}

The Caloric Suitability Indices are available for download as GeoTiff rasters for the whole world and as STATA and comma separated values files with country-level measures. The data can be downloaded at http://ozak.github.io/Caloric-Suitability-Index/ as a zip file, or individually. The links below can be used to download (or you can fork the associated Github repository which contains also an IPython notebook with some of the computations of this paper).

- All files (zip) ${ }^{6}$

- Pre-1500CE:

- Average Calories (all cells and crops) ${ }^{7}$

- Average Calories (only productive cells and crops) ${ }^{8}$

- Maximum Calories (all cells and crops) ${ }^{9}$

- Maximum Calories (only productive cells and crops) ${ }^{10}$

- Post-1500CE:

- Average Calories (all cells and crops) ${ }^{11}$

- Average Calories (only productive cells and crops) ${ }^{12}$

- Maximum Calories (all cells and crops) ${ }^{13}$

- Maximum Calories (only productive cells and crops) ${ }^{14}$

- Country-level Data:

- Stata Format

- CSV Format

- US State-level Data:

- Stata Format

- CSV Format

If you use the data, please cite this paper and also:

Oded Galor and Ömer Özak, 2014. "The Agricultural Origins of Time Preference," NBER Working Papers 20438, National Bureau of Economic Research, Inc..

\footnotetext{
${ }^{6}$ https://drive.google.com/uc?export=download\&id=0By-h7HPv1NhVM1g5aW81TzVRWjQ

${ }^{7}$ https://drive.google.com/uc? export=download\&id=0By-h7HPv1NhVeEhsRmdRWkFJX2M

${ }^{8}$ https://drive.google.com/uc? export=download\&id=0By-h7HPv1NhVcHgxa1EyOEpURUk

${ }^{9}$ https://drive.google.com/uc? export=download\&id=0By-h7HPv1NhVR2dDUm5fU2lMN2c

${ }^{10} \mathrm{https}$ ://drive.google.com/uc? export=download\&id=0By-h7HPv1NhVUzVDTXBST3d4YlE

${ }^{11}$ https://drive.google.com/uc?export=download\&id=0By-h7HPv1NhVT05GNGtaZk13S2M

${ }^{12}$ https://drive.google.com/uc?export=download\&id=0By-h7HPv1NhVcHVJcmgtb09FTXM

${ }^{13}$ https://drive.google.com/uc? export=download\&id=0By-h7HPv1NhVR2ZDemhYd1hqZms

${ }^{14}$ https://drive.google.com/uc?export=download\&id=0By-h7HPv1NhVajhjbVcyakFYMHc
} 


\section{B Additional Material}

Table 10: Continental Distribution of 48 crops (and their variants) pre-1500CE

\begin{tabular}{|c|c|c|c|}
\hline Crop & Continent & Crop & Continent \\
\hline Alfalfa & Asia, Europe & Palm Heart & North Africa, Subsahara \\
\hline Banana & Asia, Oceania, North Africa & Pearl Millet & $\begin{array}{l}\text { Asia, North Africa, Subsa- } \\
\text { hara }\end{array}$ \\
\hline Barley & Asia, Europe, North Africa & Phaseolus Bean & America \\
\hline Buckwheat & Asia & Pigeon Pea & Asia, Subsahara \\
\hline Cabbage & Europe & Rye & Europe \\
\hline Cacao & America & Sorghum & North Africa, Subsahara \\
\hline Carrot & Asia, Europe & Soybean & Asia \\
\hline Cassava & America & Sunflower & America \\
\hline Chick Pea & Europe & Sweet Potato & America \\
\hline Citrus & Asia, Europe & Tea & Asia \\
\hline Coconut & America, Oceania & Tomato & America \\
\hline Coffee & North Africa & Wetland Rice & Asia, Subsahara \\
\hline Cotton & $\begin{array}{l}\text { America, Asia, Europe, } \\
\text { North Africa, Subsahara }\end{array}$ & Wheat & Asia, Europe, North Africa \\
\hline Cowpea & $\begin{array}{l}\text { Asia, North Africa, Subsa- } \\
\text { hara }\end{array}$ & $\begin{array}{l}\text { Wheat Hard Red } \\
\text { Spring }\end{array}$ & Asia, Europe, North Africa \\
\hline Dry Pea & Europe, North Africa & $\begin{array}{l}\text { Wheat Hard Red } \\
\text { Winter }\end{array}$ & Asia, Europe, North Africa \\
\hline Flax & Asia, Europe, North Africa & Wheat Hard White & Asia, Europe, North Africa \\
\hline Foxtail Millet & Asia, Europe, North Africa & $\begin{array}{l}\text { Wheat Soft Red Win- } \\
\text { ter }\end{array}$ & Asia, Europe, North Africa \\
\hline Greengram & Asia, Subsahara & Wheat Soft White & Asia, Europe, North Africa \\
\hline Groundnuts & America & White Potato & America \\
\hline Indigo Rice & Asia, Subsahara & Yams & Asia, Subsahara \\
\hline Maize & America & Giant Yams & Asia, Subsahara \\
\hline Oat & Europe, North Africa & $\begin{array}{l}\text { Sorghum (Subtropi- } \\
\text { cal) }\end{array}$ & North Africa, Subsahara \\
\hline Oilpalm & North Africa, Subsahara & $\begin{array}{l}\text { Sorghum } \quad \text { (Tropical } \\
\text { Highland) }\end{array}$ & North Africa, Subsahara \\
\hline Olive & Europe, North Africa & $\begin{array}{l}\text { Sorghum } \quad \text { (Tropical } \\
\text { Lowland) }\end{array}$ & North Africa, Subsahara \\
\hline Onion & $\begin{array}{l}\text { America, Asia, Europe, } \\
\text { North Africa, Subsahara, } \\
\text { Oceania }\end{array}$ & White Yams & North Africa, Subsahara \\
\hline
\end{tabular}

Notes: Taken from various sources, including Crosby (1972) and Diamond (1997). 


\section{References}

Ashraf, Q. and Galor, O. (2011). Dynamics and stagnation in the malthusian epoch, The American Economic Review 101(5): 2003-2041.

Crosby, A. W. (1972). The Columbian exchange: biological and cultural consequences of 1492, Contributions in American studies, no. 2, Greenwood Pub. Co, Westport, Conn.

Diamond, J. M. (1997). Guns, germs, and steel: the fates of human societies, 1st ed edn, W.W. Norton \& Co., New York.

Galor, O. and Özak, Ö. (2014). The agricultural origins of time preference, NBER Working Paper (20438).

Özak, Ö. (2012). Distance to the technological frontier and economic development, Southern Methodist University Working Paper Series .

Ramankutty, N., Foley, J. A., Norman, J. and McSweeney, K. (2002). The global distribution of cultivable lands: current patterns and sensitivity to possible climate change, Global Ecology and Biogeography 11(5): 377-392. 